Gundacker, Roman (2018) The Descent of Kawab and Hetepheres II. Göttinger Miszellen, Bd. 256,

\title{
S. 65-91.
}

Publication date: 28.12 .18

Lengths of the embargo period: 12 months

DOI:

https://doi.org/10.1553/ERC StG 757951 R. Gundacker The Descent of Kawab and Hetepheres II

\begin{abstract}
According to the communis opinio, prince Kawab is a son of Cheops. This assumption is primarily based on G. A. Reisner's conclusions about the location of mastabahs and queen's pyramids in the East Field and on three relief fragments from mastabah G 7110/20, which W. S. Smith ingeniously assigned to a scene naming Kawab and his mother Meretites. Early after G. A. Reisner had published the first part of his view on the history of the royal family of the Fourth Dynasty, substantial critique was brought forward by W. Federn. Following the latter, Kawab should be considered a grandson of Sneferu because, apart from mastabah G 7110/20 in Gizah, another mastabah at Dahshur bears witness of him. Even though it is now safely determined that the two are neither one and the same person nor contemporaries, W. Federn's review has been taken as a starting point for further critical investigation by some scholars who came to the conclusion that Kawab was rather a son of Sneferu.
\end{abstract}

\section{Project:}

\section{'Challenging Time(s)' - A New Approach to Written Sources for Ancient Egyptian Chronology (CT):}

This project has received funding from the European Research Council (ERC) under the European Union's Horizon 2020 research and innovation programme under Grant Agreement No 757951 and is hosted at the Austrian Archaeological Institute of the Austrian Academy of Sciences.

The results published are solely within the author's responsibility and do not necessarily reflect the opinion of the European Research Council or the European Commission who must not be held responsible for either contents or their further use. 


\section{GÖTTINGER MISZELLEN}

Beiträge zur ägyptologischen Diskussion

Heft 256

Göttingen 2018 


\section{INHALTSVERZEICHNIS}

\section{KURZBEMERKUNGEN}

Backes, Burkhard: Darf man auf Unrecht treten? Zu einer Formulierung im Lebensmüden und in Sargtext 816

\section{MISZELLEN}

Bennett, James E.: Romano-Egyptian Terracotta Figurines in the Dorman Museum, Middlesbrough

Beuthe, Tatjana: The Two Brothers: A Re-evaluation of Their Kinship .......

Castañeda Reyes, José Carlos: An Approach to the Role of the nds in the Social History of Ancient Egypt

Castillos, Juan José: The Myth of Elite Redistribution in Ancient Egypt.....

Feucht, Erika: Zwei koptische Stoffe

First, Grzegorz: Zwei Grabkegel aus dem Nationalmuseum in Gdańsk (Polen)

Goddio, F. / Kuzniar, J.: Thônis-Héracléion. Poids et pierres de pivotement

Gundacker, Roman: The Descent of Kawab and Hetepheres II

Hönig, Werner: Symbolkraft der Geometrie im Alten Ägypten

King, Maiken Mosleth: The Christians of Terenouthis: a modern myth

Kitat, Sara: The Cult of God Priapus in Egypt during the Græco-Roman Period

Miatello, Luca: Inferring the Construction Process of Two Geometric Algorithms

Sakamoto, Tsubasa: Chronologie révisée des cimetières royaux de Nobadia

Shafik, Sameh: Khety of Beni Hassan and his ideal offering list

Sperveslage, Gunnar: Quoth the Raven: Nevermore! Zur frühzeitlichen Stele Nr. 127 aus Abydos 
The Descent of Kawab and Hetepheres II

\author{
Roman Gundacker* \\ Institute OREA, Austrian Academy of Sciences
}

\title{
1. Previous Discussion of Kawab's and Hetepheres II's Descent
}

According to the communis opinio, prince Kawab is a son of Cheops. ${ }^{1}$ This assumption is primarily based on G. A. Reisner's ${ }^{2}$ conclusions about the location of mastabahs and queen's pyramids in the East Field and on three relief fragments from mastabah G 7110/20, ${ }^{3}$ which W. S. Smith ingeniously assigned to a scene naming Kawab and his mother Meretites. Early after G. A. Reisner ${ }^{4}$ had published the first part of his view on the history of the royal family of the Fourth Dynasty, substantial critique was brought forward by W. Federn. ${ }^{5}$ Following the latter, Kawab should be considered a grandson of Sneferu because, apart from mastabah G 7110/20 in Gizah, another mastabah at Dahshur bears witness of him. ${ }^{6}$ Even though it is now safely determined that the two are neither one and the same person nor contemporaries, W. Federn's review has been taken as a starting point for further critical investigation by some scholars who came to the conclusion that Kawab was rather a son of Sneferu. ${ }^{7}$

Since P. Jánosi's ${ }^{8}$ substantial critique of G. A. Reisner's inference of family relations by means of tomb positions in the East Field, Kawab's genealogical scene remains the key evidence in favour of Cheops having fathered Kawab. More than ten years ago, however, I myself put forward several observations concerning Kawab's genealogical scene, ${ }^{9}$ which, nonetheless, were mostly rejected. ${ }^{10}$ Despite the fact that a number of aspects of my audacious

* Principal Investigator of the ERC Starting Grant "Challenging Time(s): A New Approach to Written Sources for Ancient Egyptian Chronology", which has received funding from the European Research Council under the European Union's Horizon 2020 research and innovation programme, grant agreement no. 757951. The results published are solely within the author's responsibility and do not necessarily reflect the opinion of the European Research Council (ERC) or the European Commission, who must not be held responsible for either contents or their further use. I would like to thank Melanie Gundacker and Annik Wüthrich for their corrections and suggestions. Needless to say, all mistakes and errors of fact or judgment are my responsibility alone.

1 Cf., above all, Reisner (1931: 240-241) \& (1942: 28, 373); Smith (1952: 124); Reisner \& Smith (1955: 3-9); Baer (1960: 140 [no. 513]); Smith (1971: 165-166, 170-171); Schmitz (1976: 55-57, 66); Porter \& Moss (1928-2012: III.2 187); Simpson (1978: 1-2); Strudwick (1986: 146 [no. 140]); Baud (1999: II 586-587 [no. 230]); Schneider (2002: 100); Dessoudeix (2008: 62-63); Dodson (2010: 58); Stadelmann (2010); Callender (2011: 71-79); hesitant also Junker (1929-1955: II 36); Martin-Pardey (1980: 378-379 [with n. 1]). Cf. Reisner (1931: 239-242) and the discussion in extenso in Reisner (1942).

3 Smith (1952: 114 [fig. 2], 124-125); Reisner \& Smith (1955: 6 [with n. 9], fig. 9); Simpson (1978: 3-4, 8, pl. VII (c)-(e), fig. 13); cf. Porter \& Moss (1928-2012: III.2 187).

4 Reisner (1927), (1927a), (1929) \& (1931: 240-241).

5 Federn (1934) \& (1935).

6 Porter \& Moss (1928-2012: III.2 893); de Morgan (1895-1903: II 23 [fig. 53]); James (1961: 10, pl. X); Ziegler (1979); Stadelmann \& Alexanian (1998: 314); Gundacker (2006: 153-172); cf. also Baer (1960: 145 [no. 534]); Schmitz (1976: 39); Strudwick (1986: 151-153 [no. 148]); Baud (1999: II 592 [no. 238]).

7 Jánosi (2005: 101-103); Gundacker (2006: 265-270, 275-284, 298) \& (2008: 28-30, 34-37).

8 Jánosi (2005: 58-60, 84-100); cf. also Lehner (1985: 41-42, 51-59, 72-74); Callender (2012).

9 Gundacker (2006: 265-270, 275-284, 298) \& (2008: 28-30, 34-37).

10 Cf., above all, Stadelmann (2010: 299 [n. 19]); Callender (2011: 71-79). 
reconstruction of the lineage of the Fourth Dynasty ${ }^{11}$ do require revision in the light of recent discoveries, ${ }^{12}$ I assume that the basic critique of W. S. Smith's reconstruction and G. A. Reisner's deductions remains valid as shall be demonstrated in this article.

\section{The Relief Fragments Commonly Attributed to Kawab’s Genealogical Scene}

During the excavations in 1924, three relief fragments were discovered, which W. S. Smith ${ }^{13}$ united to form a single scene. Unfortunately, the precise findspots of all three fragments are not known, although the excavation diaries allow for a rough approximation. According to the records, ${ }^{14}$ excavations were carried out in the street in front of mastabah $G$ 7110/20 and in the chapel of Kawab (G 7120) on $24^{\text {th }}$ December 1924:

"Street G 7100, front of G 7120, G 7120 X. The clearing of G 7100 street has reached the lowest level south of the chapel G 7120 and we are working on the lower levels in the chapel and on the higher levels north of chapel."

Judging from the registration numbers assigned to those three fragments (frag. 24-12-1000, frag. 24-12-1002, frag. 24-12-1122), they must have been found on $24^{\text {th }}$ December 1924 . It is thus possible that they were discovered inside of Kawab's chapel, but they may equally well have been found in the G 7100 street east of mastabah G 7110/20. It is unknown according to what principles the registration numbers were assigned, but in case they mirror the sequence or time of discovery, frag. 24-12-1000 and frag. 24-12-1002 must have been found in close proximity to each other while frag. 24-12-1122 belonged to another findspot.

Nevertheless it must be stated that the findspots cannot be taken as indisputable proof for the original location of the reliefs, because mastabah $G 7110 / 20$ has suffered from later (be it Ramesside or medieval) ${ }^{15}$ stone robbery stripping it off of its fine limestone casing with devastating effects for the chapels. Furthermore, it should be borne in mind that, in the $19^{\text {th }}$ and early in the $20^{\text {th }}$ century, insufficiently documented excavations were carried out near

11 Gundacker (2006: 103-314, 371-372), (2008) \& (2010).

12 Cf., e.g., the Wadi el-Jarf papyri which date Anchhaef's vizierate to the end of Cheops' reign (Tallet 2017).

13 Smith (1952: 114 [fig. 2], 124-125); Reisner \& Smith (1955: 6 [with n. 9], fig. 9); Simpson (1978: 3-4, 8, pl. VII (c)-(e), fig. 13); cf. Porter \& Moss (1928-2012: III.2 187).

14 Reisner (1924: XI 99-100); cf. also section 4 argument (3) further below.

15 It is unknown how much Ramesside looting of building materials may have impacted on Gizah and its necropoleis, but if J. Málek's (1992) suggestion is correct that Chaemwaset's restoration programme was mainly carried out in order to compensate previous devastation, a statue of Kawab (Gomaà 1973: 84, 119 [fig. 19], pl. 4, cf. also the remarks in section 5 further below), which he recovered and transferred to the temple of Ptah at Memphis, may require assessment from a new perspective (for the Memphite area in the Ramesside era, cf. Kitchen 1991; Snape 2011 \& 2017). Whether medieval quarrying continued Ramesside destruction or should be held responsible alone is unclear, but it is easy to imagine that the search for building material for the medieval Arabian monuments of Cairo contributed to the damage seen with G 7110/20 (cf., e.g., Stadelmann 2010: 296). As opposed to this, G. A. Reisner's (1927a, 1931: 240-241; cf. also Smith 1942: 523-524; Reisner \& Smith 1955: 8-9) theory of intentional demolition of some tombs at Gizah, among them mastabah G 7110/20, as part of a family feud can no longer be supported (cf., e.g., Jánosi 2005: 59-64, 101, $105,231-232,434$ [with further references]; there is no trace left of this theory in more recent works on the royal family of the Fourth Dynasty, e.g., Baud 1999; Callender 2011). 
Cheops' pyramid in the East Field which whirled around debris and, perhaps, unrecognised fragments. ${ }^{16}$ As a result of all those activities, some fragments have been relocated and found in findspots which can be identified as secondary (tertiary). One such example is frag. 26-376suppl., which has been found in the chapel of Nefretkau (G 7130) but bears remains of Kawab's name and is thus best assigned to Kawab's chapel (G 7120) opposite the street. ${ }^{17}$
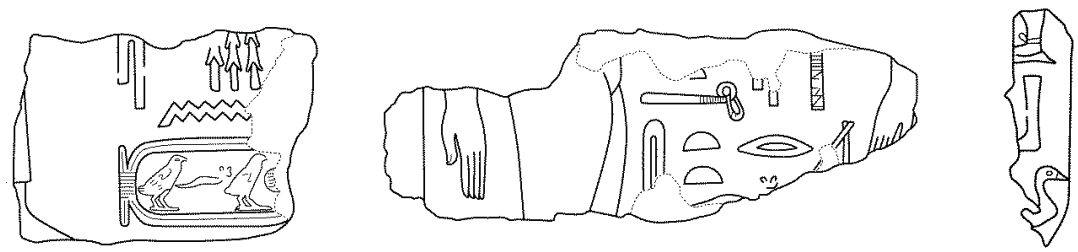

Fig. 1: From left to right: frag. 24-12-1000, frag. 24-12-1002, frag. 24-12-1122; all three relief fragments were found near mastabah G 7110/20 (drawing by L. Majerus)

Frag. 24-12-1000 shows the foot, presumably of a woman, as can be inferred from the straight leg and the close-fitting dress. The inscription in front of this figure reads $m s s n H w j=f$ - $w j$, but it is unclear whether the "folded cloth" (Gardiner S 29) should be taken as a complement of $m s j j$ "to give birth" or as a word of its own, most likely the dependent pronoun śj "her".

Frag. 24-12-1002 depicts on the left hand side the womb and the upper ends of the thighs of a woman with a hand behind. There is another hand, obviously from a second figure, on the right hand side. In between the two figures facing each other, remains of an inscription can be seen which give a woman's name (Mrjj.t-jtj=s) and portions of her titles.

The third fragment, frag. 24-12-1122, displays the vestiges of three hieroglyphs, the upper two of which face left and can be assigned to Kawab's name $[K 3=j-w]^{c} b . j$, whose figure would be expected on the right hand side of his name, whereas the lowermost hieroglyph, a "pintail duck" (Gardiner G 39), faces right and most likely formed part of a title containing the word $s 3$ "son" or s3.t "daughter". This lowermost hieroglyph opened the caption of a second figure on the left hand side, which must have been depicted face to face with the other.

\section{W. S. Smith's Reconstruction of Kawab's Genealogical Scene}

It is easy to imagine that W. S. Smith ${ }^{18}$ was enthusiastic about including all three fragments in a single scene since two of them indicate two facing figures (frag. 24-12-1000, frag. 24-121122 ) and the third displays an inscription relating the birth of someone to Cheops (frag. 2412-1000). Nevertheless, W. S. Smith remained somewhat hesitant whether all three fragments came from one and the same relief because he could not succeed in providing a convincing

16 Cf. G. A. Reisner's (1924: XI 99) entry in the excavation diary for $24^{\text {th }}$ December 1924, when work was done in and around the chapel of Kawab (G 7120): "The upper deposits of debris over this whole area have been broken and mixed by recent excavations."

17 Simpson (1978: 18, pl. XXIX, fig. 23). Or was there a depiction of Kawab in the chapel of his sister-in-law?

18 Smith (1952: 114 [fig. 2], 124-125); Reisner \& Smith (1955: 6 [with n. 9], fig. 9); Simpson (1978: 3-4, 8, pl. VII (c)-(e), fig. 13); cf. Porter \& Moss (1928-2012: III.2 187). 
restoration of the inscription involving both frag. 24-12-1122 and frag. 24-12-1002. ${ }^{19}$ More basically, the entire reconstruction of the relief is based on the observation ${ }^{20}$ that the figure on the right hand side must have been depicted with the right hand hanging in front, which is indicative of a man. Accordingly, the scene must depict Kawab, the tomb owner, and his mother facing each other. In view of that, it was also reasonable to assign the unwieldy frag. 24-12-1122 to this scene. As a result, the following reconstruction was proposed (fig. 2):

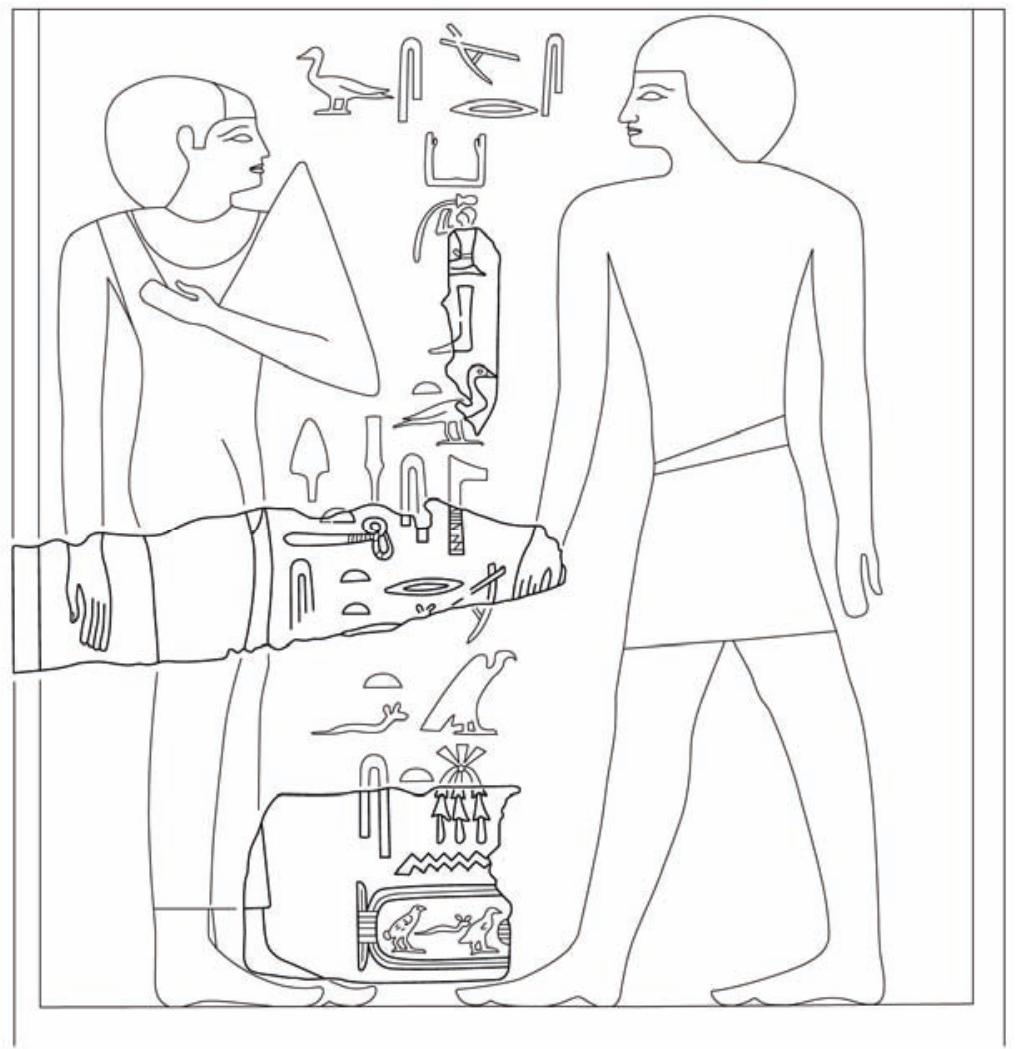

Fig. 2: The genealogical scene depicting Kawab and his mother after W. S. Smith (originally published in Reisner \& Smith 1955: fig. 9 = Simpson 1978: fig. 13; drawing by L. Majerus, first published in Gundacker 2006: 467 [fig. 48a] = 2008: 28 [fig. 5])

19 W. S. Smith expressed his hesitation already in 1952, when he offered a reconstruction only comprising frag. 24-12-1000 and frag. 24-12-1002 (Smith 1952: 114 [fig. 2], 124 [n. 16]). Three years later, he thought that this hesitation might be overcome with an improved reconstruction of the inscription (Reisner \& Smith 1955: 6 [with n. 9], fig. 9). However, this actually has never been achieved. In 1978, W. K. Simpson repeated the problems when joining all three fragments in a single scene (Simpson 1978: 3-4, 8, pl. VII (c)-(e), fig. 13), but, despite that, the version comprising all three fragments has become a general point of reference.

20 Smith (1952: 124 [n. 16]). 
Rather soon, this reconstruction was criticised because of the unusual and unparalleled title s3.t $n \underline{t} r=s^{\prime}$ "daughter of her god" by B. Schmitz ${ }^{21}$ and many others. ${ }^{22}$ V. G. Callender ${ }^{23}$ finally provided a convincing solution and suggested to read (hm.t-)ntr $\underline{T} 3 j-s p=f$ "priestess of Tjaysepef" 24 instead. This alteration necessitated further changes, above all to exclude frag. 24-121122 because the "bull on divine standard" (Gardiner E $1+\mathrm{R} 12 \mathrm{var}$.) requires more space and does not fit the traces of a "pintail duck" (Gardiner G 39) on this very fragment.

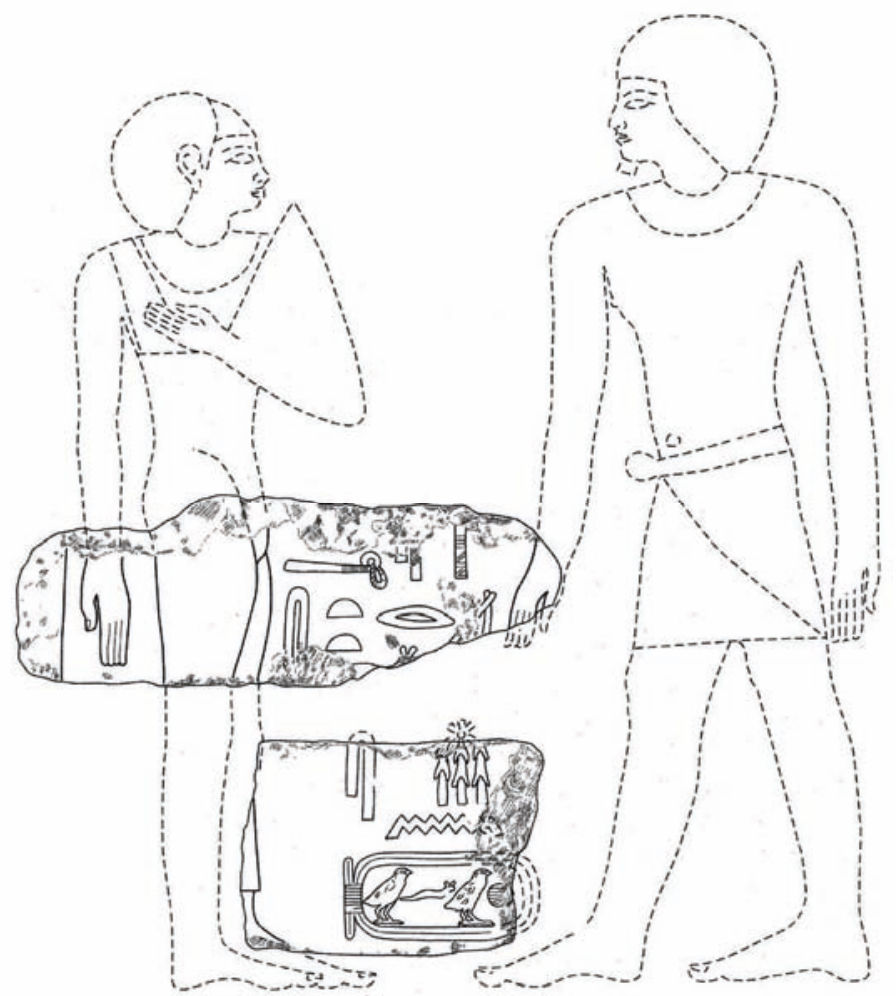

Fig. 3: The genealogical scene depicting Kawab and his mother after W. S. Smith in V. G. Callender's adaption (Smith 1952: 114 [fig. 2]; Callender 2011: 76 [fig. 40])

V. G. Callender thus returned to W. S. Smith's more cautious version with a few additional changes. The most obvious modification is the reduction of space between frag. 24-12-1000

21 Schmitz (1976: 135-136).

22 Seipel (1980: 99); Troy (1986: 98); Callender (1992: III 44) \& (2011: 72); Baud (1999: II 469 [no. 85]); Roth (2001: 481); Gundacker (2006: 266-267) \& (2008: 24). L. Kuchman Sabbahy's (1982: 52) conjecture wr.thts s' "great of favour" was met with proper scepticism by V. G. Callender (2011: 72), because this would not fit the clearly discernible traces of the "cloth wound on a pole, emblem of divinity" (Gardiner R 8).

23 Callender (1992: III fig. 8 [after p. 43]) \& (2011: 72-73 [with fig. 38], 78).

24 For this deity, cf. Helck (1986); Leitz (2002-2003: VII 459). 
and frag. 24-12-1002. However, it is impossible to move those fragments that close together because space would be insufficient for accommodating one group of full height hieroglyphs, but space would be too much for assuming a blank (fig. 3). Furthermore, the queen's titles and name would appear strangely crowded in view of the adjoining void, and W. S. Smith's brilliant conjecture $m w . t=f$ "his mother", which closely follows the genealogical scene of Chaefchufu I, ${ }^{25}$ would find no space. As a consequence, we would have to judge the phrase $m s j j[. t] n H w j=f-w j$ as a participial epithet of the queen herself, who thus were a daughter of Cheops ("who was born to Cheops"). We can thus exclude this attempt of repositioning the fragments and follow W. S. Smith who suggested a distance of about one hieroglyphic square between frag. 24-12-1000 and frag. 24-12-1002 in order to accommodate his conjecture.

In addition, W. Seipel ${ }^{26}$ and V. G. Callender ${ }^{27}$ questioned the title hrp.t śšmtj.w šnd.t "director of the butchers of the Acacia sanctuary" 28 because the "tree" (Gardiner M 1) and the "sceptre of authority" (Gardiner S 42) are positioned atop the "knife-sharpener as carried by butcher (Old Kingdom)" (Gardiner T 33), the latter sign is unexpectedly reversed, and the anticipated determinative of šnd.t "Acacia sanctuary", a "house" (Gardiner O 1), must be missing. However, it is not uncommon that the "tree" (Gardiner M 1) and the "sceptre of authority" (Gardiner S 42) precede the rest of this title as is demonstrated by attestations of this title for queen Hetepheres $\mathrm{II}^{29}$ and queen Chamerernebti II. ${ }^{30}$ It also should be noted that, in the scene from G 7110/20, the queen's name and the preserved parts of her titles are tightly arranged due to space constraints. Reversing the "knife-sharpener as carried by butcher (Old Kingdom)" (Gardiner T 33) was thus a clever and elegant way to utilise efficiently the space available and to avoid a collision with the "folded cloth" (Gardiner S 29) of the name Meretites. ${ }^{31}$ As part of the queens' title hrp.t śšmtj.w šnd.t "director of the butchers of the Acacia sanctuary", the "house" (Gardiner O 1) indeed is customarily found. Nevertheless, on the one hand, it is missing from all writings of this title of Hetepheres $\mathrm{I}^{32}$ and it is usually missing in the simple designation of butchers assigned to this institution. ${ }^{33}$ Therefore, the missing determinative should not be taken as an unsurmountable obstacle. If need be, one might speculate whether the lack of space resulted in placing the "house" (Gardiner O 1) at the very beginning of this title and in grouping it together with the "tree" (Gardiner M 1) in a compound like $\}$, the kind of which is well known from $\uparrow$ prw-'nh " "house of life', temple library" 34 etc.

25 Simpson (1978: 11, pl. XVI (a), fig. 26).

26 Seipel (1980: 99).

27 Callender (2011: 72).

28 For this title, cf. Fischer (1960: 179-190); Edel (1970); Baud (1999: I 342-343); Callender (2011: 163, 329).

29 Apart from the determinative of the "house" (Gardiner O 1), the writing of this title of Hetepheres II in G 7530sub, the rock tomb of her daughter Meresanch III (Reisner 1927a: 67 [fig. 5]; Dunham \& Simpson 1974: fig. 7), is exactly the same as that conjecturally restored by W. S. Smith.

30 Cf. the depiction of this queen and her son, Chuenre, in the latter's tomb (MQ1, Reisner 1934: 11 [fig. 10]).

31 Examples for this kind of reversal due to practical reasons of space constraints can be found all throughout the Old Kingdom, cf., e.g., the "folded cloth" (Gardiner S 29) in the title hir.j-šst 3 "privy councillor" on the jamb of a door or false-door of Qedshepses from Saqqarah (de Morgan 1895-1903: I 13 [fig. 13]).

32 Reisner \& Smith (1955: pl. 28-29 [carrying chair], fig. 40 [lid of inlaid box]).

33 Cf. the collection of examples provided by Fischer (1960: 181-184) starting with Metjen (Fischer 1960: pl. XLVIII); for further examples, cf. attestations recorded by Hannig (2003: 1314).

34 Gardiner (1938); Gundacker (in print); for Old Kingdom attestations, cf. Hannig (2003: 451). 


\section{An Alternative Reconstruction of the Scene: The Descent of Hetepheres II}

Apart from minor (ortho)graphic details discussed on the previous pages, for which plausible explanations can be found, the reconstructions of W. S. Smith and of V. G. Callender face a number of fundamental difficulties, which make me doubt the depiction of Kawab: ${ }^{35}$

(1) Even though two of the fragments display two figures facing each other (frag. 24-121000, frag. 24-12-1122) and the inscription on the third mentions the birth of someone to Cheops (frag. 24-12-1000), there is no direct join between any two of the three fragments (frag. 24-12-1000, frag. 24-12-1002, frag. 24-12-1122). It is thus impossible to demonstrate convincingly that they all fit into a single scene, ${ }^{36}$ even though it would be surprising if the three fragments would belong to three different scenes. This problem is less urgent when only frag. 24-12-1000 and frag. 24-12-1002 are assigned to one and the same scene as is the case in W. S. Smith's more cautious and V. G. Callender's reconstruction. If this be accepted, there remains one paramount question which has never been asked: What to do with frag. 24-12-1122? Were there two genealogical scenes stating the descent of Kawab, and if so, why? Or was there one for Hetepheres II?

(2) W. S. Smith ${ }^{37}$ observed that, on frag. 24-12-1002, the figure on the right hand side, the child of the figure on the left hand side, was represented with the right hand hanging in front. Since this is the usual pose of a man, the depicted child must be Kawab. This observation has never been questioned, but it must not be accepted without further discussion. It is true that most high-ranking women, whenever they were depicted in a standing posture, display one arm raised to the chest, be it with the hand empty or holding a sceptre, ${ }^{38}$ or to the nose in order to smell a lotus blossom. ${ }^{39}$ But already the Fourth Dynasty does know of examples of standing women with both arms hanging. ${ }^{40} \mathrm{It}$ is thus possible that the hand on the right edge of frag. 24-12-1002 belonged to the representation of a daughter, not a son, of Meretites. The distribution of the hieroglyphs on frag. 24-12-1002 unambiguously indicates that queen Meretites, the mother depicted on the left hand side, was shown with one arm raised. Since mother and daughter were not of equal rank - the earlier a king's wife, the latter married to prince Kawab -, the rare posture of the daughter with both arms hanging could express her subordinate state.

(3) As mentioned further above, the excavation diaries do not record the exact findspot for any of the three fragments (frag. 24-12-1000, frag. 24-12-1002, frag. 24-12-1122), ${ }^{41}$ but they do state that the stratification at Kawab's chapel (G 7120) and in the G 7100 street

35 The core of the subsequently presented observations has been presented in my magisterial dissertation and a subsequent article (Gundacker 2006: 266-268 \& 2008: 28-29).

36 Cf. already Schmitz (1976: 135-136).

37 Smith (1952: 124 [n. 16]).

38 Cf., e.g., depictions of Meresanch III and of her mother Hetephers II in G 7530sub (Dunham \& Simpson 1974: fig. 3a, 6, 7); cf. also the material collected by Harpur (1987) and Flentye (2006).

39 Cf., e.g., depictions of Meresanch III in G 7530sub (Dunham \& Simpson 1974: fig. 3b, 12); cf. also the material collected by Harpur (1987) and Flentye (2006).

40 Cf., e.g., depictions of Djefatsen, wife of Pehenwika (Lepsius 1849-1913: II pl. 46; Harpur 1987: fig. 188) or of Chaemsechem's wife in G 7660 (Flentye 2006: pl. 107-108; Porter \& Moss 1928-2012: III.2 201-202).

41 Cf. section 2 further above. For displaced fragments from G 7110/20, cf. Simpson (1978: 4). 
was disturbed and the debris mixed by earlier excavations. It is thus impossible to say whether a specific fragment has been found near its original placement or whether it lay further off from where it came, e.g., from the chapel of Hetepheres II (G 7110). ${ }^{42}$ As a matter of fact, one has to admit that it is highly unlikely that all three fragments came from Hetepheres II's chapel (G 7110) as long as there is no plausible explanation for a supposed transfer of a large quantity of relief fragments. The only possibility I can think of would be a workshop near Kawab's chapel (G 7120) from the time of the removal of the limestone blocks, ${ }^{43}$ but the records provide no evidence in favour of such a proposal. It is therefore practically certain that frag. 24-12-1122 originated in Kawab's chapel (G 7120). However, the case is different with frag. 24-12-1000 and frag. 24-12-1002. On the one hand, frag. 24-12-1000 and frag. 24-12-1002 must have been found in one of the upper stratigraphic layers, which were disturbed by earlier activity, according to their registration numbers. Moreover, if the registration numbers indicate that those two fragments belonged to a single findspot, they may have found their way from Hetepheres II's chapel (G 7110) together. If so, one would expect that they were found rather in the G 7100 street than in Kawab's chapel (G 7120). On the other hand, the comparably large size of frag. 24-12-1000 and frag. 24-12-1002 renders their displacement rather unlikely and speaks in favour of an origin in Kawab's chapel (G 7120). After all, the archaeological data is insufficient to draw definitive conclusions on this matter.

The north and south chapels of a mastabah with two burial apartments are often assigned to the tomb owner (south) and his wife (north) much too mechanically. ${ }^{44}$ Even if, in this instance, it could be shown that the northern chapel (G 7110) was exclusively dedicated to the mortuary cult of Hetepheres II and the southern chapel (G 7120) solely to that of Kawab, it would be no surprise to find depictions of the spouses in either chapel, in particular in Kawab's much more spacious cult installation. And, indeed, the presence of Kawab's wife in his chapel (G 7120) is proved by several fragments:

Frag. 24-12-1125, ${ }^{45}$ which is assigned to the west wall of the doorway connecting the portico (D) with chamber (C) by W. S. Smith and W. K. Simpson, shows an inscription [htp rdj.w Jnpw ...] wśr[.tj] śpsśs.tj hr ntrr-9 "[A boon which Anubis gives ... $]^{46}$ so that [she] may become powerful ${ }^{47}$ and noble before the Great God"

42 V. G. Callender's (2011: 77 [with n. 34]) emphatic statements "that these fragments were discovered in Kawab's chapel, not the chapel of his wife: therefore, it would be strange to have the queen not facing the tomb owner: one would expect that she would be facing her son, not her (probable) daughter" and "... it is more likely that the fragment came from the wall beside the place where Reisner found it." is thus not in line with the excavation records. W. K. Simpson's (1978: 3) wording "To the southern façade [scil. of the interior chapel, i.e. room (A)] Smith has assigned three fragments ..." proves that the findspot of all three fragments was unknown to him and that W. S. Smith conjecturally placed the relief following Chaefchufu I's example.

43 In Meidum, a Ramesside storing place was found which was directly connected to the dismantling of the limestone casing of the pyramid, cf. Posener-Kriéger (1991: 17-21); Verner (2001: 368-369).

44 Cf. Callender (2002); Jánosi (2002).

45 Simpson (1978: 2, pl. V (a), fig. 5 (B), 10 (A)).

46 For the core of the offering formula, cf. Lapp (1986: §§ 1-58).

47 The "bread" (Gardiner X 1) of the pseudoparticipial desinence of wśr.tj is lost, but the peculiar edge under the "head and neck of a canine animal" (Gardiner F 12) and the "folded cloth" (Gardiner S 29) may be explained as the result of a "bread" (Gardiner X 1) breaking away. The grammar of this formula (Lapp 1986: 
which, no doubt, displays the desinence of the third person feminine singular of the pseudoparticiple šsśs.tj and thus must refer to Hetepheres II, not to Kawab.

On frag. 24-12-859, ${ }^{48}$ a few hieroglyphs have been preserved which most probably come from a caption $[\ldots h m . t=f \quad m r j j] . t=f[s 3 . t \quad n j] s w[t h t p-h r=s]$ " [... his wife whom] he lo[ves, the] kin[g's daughter Hetepheres II]". 49 This fragment may have belonged to room (A), where, to the right of the false door, Kawab is depicted with a son before him at his feet and his wife behind him (preserved in situ) ${ }^{50}$

According to W. S. Smith's and W. K. Simpson's reconstruction, ${ }^{51}$ frag. 24-12-861, which belongs to the western portion of the north wall of room (B), displays traces of a caption of Kawab's wife $[\ldots h m . t=f m] r j j . t=f \ldots$ " [ $[\ldots$ his wife whom $]$ he loves ...".52 However, this suggestion must be judged with due caution. If the traces at the lower edge do represent a "mouth" (Gardiner D 21), one might alternatively suggest the formula $[\ldots h] r j t j=f$ " $[\ldots$ be $]$ fore his father" 53 which would have to refer to Kawab. Since this particular epithet is found nowhere else in the remains of mastabah G 7110/20, W. S. Smith's and W. K. Simpson's original suggestion that this refers to the wife of Kawab, Hetepheres II, appears much more appealing. Be this as it may, in view of the reconstruction of the entire ensemble of scenes ${ }^{54}$ it seems very likely that frag. 24-12-861 should be lifted up in order to allow for the accommodation of an additional line with the name of either Hetepheres II or Kawab; at the same time, this would permit to insert a line with titles above Kawab's name on frag. 24-12-1128. This instance thus remains uncertain.

To sum up, it is irrelevant for the identification of the figure on the right hand side of frag. 24-12-1002 whether frag. 24-12-1000 and frag. 24-12-1002 were discovered in or near Kawab's chapel (G 7120) or not and whether they formed part of the decoration programme of this cult installation or not. But even in case all three fragments (frag. 2412-1000, frag. 24-12-1002, frag. 24-12-1122) formed part of the relief decoration of Kawab's chapel (G 7120), one can find sufficient remains of representations of Hetepheres II in it in order to argue a genealogical scene of hers for this chapel.

(4) One of the most striking features of W. S. Smith's reconstructions ${ }^{55}$ is that he did not attempt at completing the cartouche around Cheops' name on frag. 24-12-1000. In my magisterial dissertation, ${ }^{56} \mathrm{I}$ indicated that this would have been impossible because the

$\S 339)$ is evident in the light of further examples found in the chapels of Chaefchufu I (G 7140), .. wsr.j spss.j ... "... so that he may become powerful and noble ..." (Simpson: 1978: 10, pl. XV (b), fig. 25), and of Meresanch III (G 7530sub), ... 3h.tj špsś.tj ... “... so that she may become transfigured and noble ...” (Simpson 1974: pl. II, fig. 3b). For further examples of this early kind of formulae, cf. Lapp (1986: § 339).

48 Simpson (1978: fig. 15).

49 Gundacker (2006: 277) \& (2008: 34).

50 Simpson (1978: 4, pl. VII (a), fig. 5, 15).

51 Simpson (1978: 2, pl. V (b), fig. 10 (C)).

52 This view is supported by Flentye (2006: 48).

53 Cf. Junker (1929-1955: I 33-34); Schmitz (1976: 65-79).

54 Simpson (1978: 2, pl. V (b), fig. 10 (C)).

55 Smith (1952: 114 [fig. 2], 124-125); Reisner \& Smith (1955: 6 [with n. 9], fig. 9); Simpson (1978: 3-4, 8, pl. VII (c)-(e), fig. 13); cf. Porter \& Moss (1928-2012: III.2 187).

56 Gundacker (2006: 267) \& (2008: 29). 
cartouche would strike the foot of Kawab, which found V. G. Callender's ${ }^{57}$ agreement. An additional problem, which neither of them noticed, is the fact that in a reconstruction of the scene embracing all three fragments, Kawab would be mentioned without any title. This appears doubtful at any rate, and, when compared to the genealogical scene of Chaefchufu I, ${ }^{58}$ this is rendered impossible because one would expect to find the title $s^{3}$ njswt "king's son" (or a variant of it) with the child (son). Both these problems, but specifically that with the cartouche, render either reconstruction of W. S. Smith unfeasible.

V. G. Callender ${ }^{59}$ drew attention to some closely related details which disprove W. S. Smith's approach. According to her observations, W. S. Smith had rotated frag. 24-12-1000 clockwise and frag. 24-12-1002 counterclockwise for unknown reasons. As a result, the inscriptions of both fragments appeared slanting and the hand of the figure on the right hand side was placed higher up from the base line than the hand of queen Meretites. ${ }^{60}$ She thus corrected the positioning of either fragment and moved them closer together with the result that Kawab's foot and the cartouche do not touch each other and that the hands of both figures start at equal distance from the base line (cf. fig. 3). However, I am not sure that both hands must start at exactly the same height. In the tomb of Nebemachet, a son of Meresanch III, ${ }^{61}$ the hand of his wife, who is standing behind him, starts slightly lower than her husband's hand. The same holds true for the genealogical scene of Chaefchufu $\mathrm{I}^{62}$ the hand of whose mother starts a bit closer to the base line than her son's hand as the bracelets on their wrists demonstrate. However, the hand of the wife of Chaemsechem, ${ }^{63}$ who, again, is standing behind her husband, starts slightly higher than the hand of her husband.

Besides, the scene after V. G. Callender looks strange for several reasons. Above all, queen Meretites on the left hand side appears unexpectedly small in relation to her then oversized hand on frag. 24-12-1002. Furthermore, Kawab on the right hand side looks bigger and sturdier than his mother to such an extent that it appears incredible per $s e$ and, in particular, when compared to the genealogical scene of Chaefchufu I and his mother. ${ }^{64}$ In addition, Kawab's representation appears bent forward to a certain degree. The rotation of frag. 24-12-1002 has obviously gone so far that the inscription now is sloping to the right hand side and that the limiting line of the scene on the left hand side, behind queen Meretites, has become oblique. Also, we should keep in mind that the space between frag. 24-12-1000 and frag. 24-12-1002 does not allow for the insertion of text although it is much too big to be accepted as a blank space. ${ }^{65}$ The supposed corrections thus cannot emend the deficiencies of W. S. Smith's reconstructions adequately.

Callender (2011: 77).

58 Simpson (1978: 11, pl. XVI (a), fig. 26).

59 Callender (2011: 77).

60 Since V. G. Callender's (2011: 77) remarks on the outline of Meretites' dress on frag. 24-12-1000 tackle a convention which, as she states, "seldom" knows exceptions, this detail need not be discussed here further.

${ }_{61}$ LG 86 (Lepsius 1849-1913: II pl. 13; Hassan 1932-1960: IV 140 [fig. 81], pl. XXXVIII).

62 Simpson (1978: 11, pl. XVI (a), fig. 26).

${ }_{63}$ G 7660 (Flentye 2006: pl. 107-108; Porter \& Moss 1928-2012: III.2 201-202).

${ }_{64}$ Simpson (1978: 11, pl. XVI (a), fig. 26).

65 Cf. section 3 further above. 
(5) The firmest piece of evidence against the postulate of a male (Kawab) on the right hand side of this scene, which I had stated for the first time in my magisterial dissertation, ${ }^{66}$ is certainly a grammatical one. In Chaefchufu I's ${ }^{67}$ roughly contemporaneous genealogical scene, the caption of his mother reads 1 , II mw.t=f mśj.t św m3.t Hrw Śth wr.t-[htśs wr.t-ḥsw.t /// ///] "his mother, who has given birth to him, she who beholds Horus and Seth, she great [of favour, she great of praise /// ///]". It is noteworthy that the participle $m s j . t$ "(she) who has given birth" is only spelled with "three foxes' skins tied together" (Gardiner F 31) and a "bread" (Gardiner X 1) but without a "folded cloth" (Gardiner S 29) as phonetic complement. The participial phrase is worded straight forward without elliptical omissions and thus exhibits the dependent pronoun sw "him" as the accusative object of the verb (participle), and one would expect a pursuant scene and caption in mastabah G 7110/20. On fragment 24-12-1000, however, the text goes "bread" (Gardiner X 1) safely restored because of the distance between the other hieroglyphs. In case a son is restored, three peculiarities become salient: First, the participle mśj.t "(she) who has given birth" is written with a "folded cloth" (Gardiner S 29) as phonetic complement. Second, the dependent personal pronoun $s w$ "him" is missing. Third, the father of the child is explicitly stated, which is uncommon in case of a prince or princess. The first and second irregularity are easy to resolve if the participle mśj.t "(she) who has given birth" is accepted to comprise "three foxes' skins tied together" (Gardiner F 31) and a "bread" (Gardiner X 1) and if the "folded cloth" (Gardiner S 29) is not viewed as a phonetic complement, but as the dependent personal pronoun $s j$ "her". ${ }^{68}$ Accordingly, the genealogical scene covering frag. 24-12-1000 and frag. 24-12-1002 must be viewed as an illustration of a daughter's descent, which, in this context, must be Hetepheres II.

As it seems, J. P. Allen drew the same conclusion at approximately the same time as I did. He must have considered the commonly accepted reading as flawed and must have understood the dependent personal pronoun $s j$ "her" instead. However, his analysis has not been published, and I know of it only from a short reference by L. A. Flentye: 69

"Allen considers the translation of the inscription to be incorrect, so that Meretites might actually be facing her daughter, Hetepheres II."

As a matter of fact, Hetepheres II mentions her own father for a second time in the

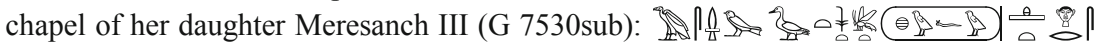
$m w . t=\hat{s}$ wr.t-ḥtś Htp-ḥr=śs s3.t njśst-bjt H్wj=f-wj "her (scil. Meresanch III's) mother, she

66 Gundacker (2006: 267-268) \& (2008: 29).

${ }_{67}$ Simpson (1978: 11, pl. XVI (a), fig. 26). Given that the restoration of the titles is correct, the name of the queen, which unfortunately is lost, can only cover two hieroglyphic squares.

68 Very rarely, the dependent pronoun $s w$ "him" is attested in a defective writing comprising only the "folded cloth" (Gardiner S 29). However, in the Old Kingdom, the examples of this extraordinary spelling are confined to the usage of $s w$ as the copula in a rare type of substantival sentences (Gundacker 2010a \& 2016; for the New Kingdom, cf., e.g., Gomaà 1973: 67 [n. b]) and thus cannot be assumed in the present case.

69 Flentye (2006: 50). 
great of favour, Hetepheres, the daughter of the King of Upper and Lower Egypt Cheops". ${ }^{70}$ In the very same scene, her daughter, Meresanch III, is referred to as

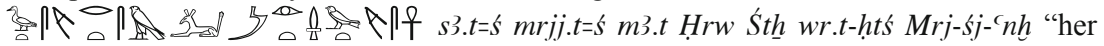
daughter, whom she loves, she who beholds Horus and Seth, she great of favour, Meresanch". And again, the father, this time of Meresanch III, is mentioned (ㄷㄴ $j t j=s \ldots K 3=j-w^{c} b . j$ "her father ... Kawab"), which finds a plausible explanation when the descent of Meresanch III is viewed in the light of the title s3.t-njswt nj.t h.t=f "king's daughter of his body" "71 which she bore. Since for the mother of Meresanch III, Hetepheres II, the titles of a queen are amply attested, she obviously must have wedded a king after her marriage with Kawab. This king as Meresanch III's stepfather - Redjedef according to the communis opinio -, must have granted her the title of a princess. Therefore, it became necessary to state explicitly her (biological) father, i.e., Kawab. ${ }^{72}$ It is thus reasonable to assume that a similarly complicated family situation urged Hetepheres II to mention her own (biological) father in the chapel of her daughter Meresanch III (G 7530sub), and in her own genealogical scene from mastabah G 7110/20.

The key evidence for understanding why the father of Meretites' child is given in the scene of descent from mastabah G 7110/20 (frag. 24-12-1000) is the so-called stela of Meretites. ${ }^{73}$ This monument, which unfortunately is now lost and has been recorded only insufficiently, showed two exceptional titles: "she great of favour of Sneferu", favour of Cheops". It is clear right from the beginning, that the "club used by fullers in washing" (Gardiner U 36) must stand for another hieroglyph, most likely the similar and otherwise extremely rare hieroglyph usually found with the word hts "favour" ("a kind of sceptre" (Gardiner S 168 and variants)). V. G. Callender ${ }^{74}$ proposed an entirely different interpretation and read wr.t-hm.(w)t-Snfrw "greatest of the priests of Sneferu" and $w r . t-h m .(w) t-H w j=f-w j$ "greatest of the priests of Cheops" instead. She assumed that the common title hm.t-ntr "priestess" was abbreviated with the king's name supplementing $n t \underline{r}$ "god" and that the genitival adjective $n j . t$ was the result of a slip of memory of E. de Rougé and A. Mariette, thus never forming part of the text. However, it seems questionable to posit an otherwise unparalleled title in order to avoid a simple emendation which is based on the confusion of two similarly looking hieroglyphs during the early phases of Egyptology, when the identification of certain hieroglyphs was still demanding. Furthermore, it should be borne in mind that some officials combined their titles with the names of kings via indirect genitives ${ }^{75}$ in order to express that they held those titles during the reigns of several kings. Examples include, among others, an offi-

70 Dunham \& Simpson (1974: pl. IV, fig. 4).

71 Dunham \& Simpson (1974: 25).

72 Cf. in general and for further references Dunham \& Simpson (1974: passim); Schmitz (1976: 46-48, 109113); Baud (1999: II 461-463 [no. 76]); Gundacker (2006: 265-270) \& (2008); Callender (2011: 119-129).

73 de Rougé (1866: 37-39) \& (1877-1879: I pl. 62); Mariette (1885: 565); Smith (1952: 115 [fig. 3]); Reisner \& Smith (1955: 6, pl. 8a); Schmitz (1976: 55, 135-136); Baud (1999: II 468-46985]); Jánosi (1996: 10); Gundacker (2006: 265-270) \& (2008); Callender (2011: 66-79); cf. also Porter \& Moss (1928-2012: III.2 187).

74 Callender (2011: 69-70) \& (2012: 71-75).

75 Fischer (1964) \& (1996: 29-31, 39). 
cial of the Fourth Dynasty of unknown name who served as $h \underline{d}$ nj Snfrw "overseer of the treasury of Sneferu", $H w j=f-w j$ "overseer of the treasury of Cheops", $\underline{d} d j=f$ "[overseer of the treasury of] Redjedef" and ${ }^{2}$ $\left[H^{c} j=f-R^{c} w\right]$ "overseer of the treasury of [Chephren]"76 and Shepsesptah of Saqqarah" who served as est of directors of craftsmanship in both houses of Sahure" and, although those titles are lost and have to be restored conjecturally, ${ }^{78}$ wr-hrp.w-hmw.t m pr.wj $n j N f r$-jrw-k3-R $R^{c} w$ "greatest of directors of craftsmanship in both houses of Neferirkare", wr-hrp.w-hmw.t $m$ pr.wj $n j R^{c} w-n f r=f$ "greatest of directors of craftsmanship in both houses of Reneferef", wr-hrp.w-hmww.t m pr.wj nj $S^{\xi} p s^{s}-k^{3}-R^{c} w$ "greatest of directors of craftsmanship in both houses of Shepseskare". There is thus no reason to decline the commonly accepted analysis of Meretites' titles as wr.t-httś nj.t Śnfrw "she great of favour of Sneferu" and $w r . t$-hts's nj.t Hwj=f-wj "she great of favour of Cheops". Consequently, they clearly indicate a close relationship of Meretites to both Sneferu and Cheops, perhaps as a king's wife if the title under discussion can be taken at face value. ${ }^{79}$ The quoted titles of officials and those of queen Meretites share yet another remarkable feature which is that they all lack the otherwise frequently met honorific transposition of the king's name.

The reason for mentioning the name of the father to whom Meretites bore a child (Hetepheres II) on frag. 24-12-1000 is thus simply that there were two possibilities of descent: Hetepheres II could have been a daughter of Sneferu or of Cheops via Meretites. In the case of Meresanch III, the same can be observed. Theoretically, she could have been a daughter of Kawab or of a king, most likely Redjedef, which demanded to state Kawab as her true father in order to avoid misunderstandings given that, secondarily, she had been granted the title of s3.t-njsswt nj.t h.t=f "king's daughter of his body".

In summary, it appears prudent to separate frag. 24-12-1122 from the others and to attempt at reconstructing a scene of descent based on frag. 24-12-1000 and frag. 24-12-1002 alone. The hanging hand of the figure standing on the right hand side of the scene need not necessarily be a male, but it can be a female. It is impossible to identify the actual findspot of frag. 24-121000 and frag. 24-12-1002, which have probably been found in or near the chapel of Kawab (G 7120), but even if they were found there, it cannot be excluded that they originated in Hetepheres II's chapel (G 7110). Furthermore, there is no sound reason to assume that a scene relating her descent was inappropriate for the cult chapel usually (and simplistically) assigned

76 Porter \& Moss (1928-2012: III.2 760); Strudwick (1985: 45-51, pl. IV) \& (1986: 169-170); Fischer (1996: 29-30, $39=$ pl. 5).

77 Porter \& Moss (1928-2012: III.2 464); Mariette (1885: 112-113, 451-453); Sethe (1933: 51 (11)-53 (13)); James (1961: 17, pl. XVII); Baud (1999: II 452-454 [no. 68]) \& (2005: 95-96); Dorman (2002); Kloth (2002: 15-16 [no. 29], passim); Gundacker (2015); cf. also Jones (2001: no. 490).

78 Cf. Gundacker (2015); Sabu Ibebi, perhaps a grandchild of Shepsesptah of Saqqarah (Porter \& Moss 19282012: III.2 460; Mariette 1885: 412-415; Sethe 1933: 82 (3)-84 (6); Borchardt 1937-1964: II 31-34, pl. 65; Kloth 2002: 30 [no. 64]; el-Khadragy 2005; cf. also Jones 2001: no. 1451), bore a set of structurally identical titles which, however, display the expected honorific transposition of the king's name.

79 Cf. for this issue the discussion and the references Baud (1999: II 468-469 [no. 85]); Gundacker (2006: 265270) \& (2008); Callender (2011: 66-79). 
to Kawab alone. Even though the exact placement of frag. 24-12-1000 and frag. 24-12-1002 requires moderate modification, they cannot be moved too much in consideration of their text. Moreover, it must be said that the inscription on frag. 24-12-1000 displays the third person feminine singular form of the dependent personal pronoun, s $j j$ "her", which must denote a daughter, not a son. And finally, the statement on frag. 24-12-1000 that the child borne by Meretites was fathered by Cheops is entirely in line with her genealogical statement in the chapel of Meresanch III (G 7530sub). At the same time, the personal circumstances of Meretites, who perhaps was the wife of both Sneferu and Cheops, ${ }^{80}$ required a clarifying testimony concerning Hetepheres II's descent. All this taken together requires a modified reconstruction of the genealogical scene with Meretites as the mother of Hetepheres II (fig. 4).

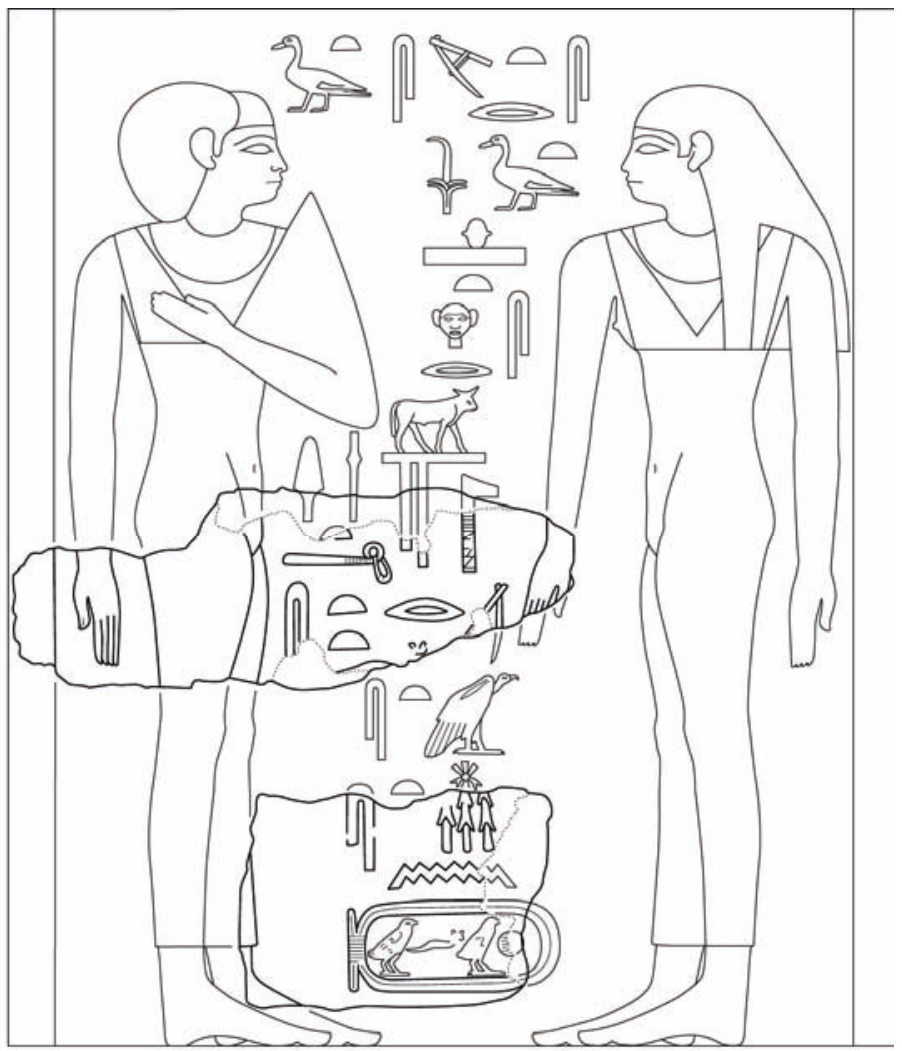

Fig. 4: The genealogical scene depicting Hetepheres II and her mother Meretites (originally published in Gundacker 2006: 467 [fig. 48b] = 2008: 29 [fig. 7]; drawing by L. Majerus with slight modifications by R. Gundacker)

80 For the ongoing discussion of this issue and for additional bibliographical references, cf. Baud (1999: II 468469 [no. 485]); Callender (2011: 73-74) \& (2012: 71-75). 
5. Fragment 24-12-1122: A Fragment from a Genealogical Scene of Kawab

As soon as frag. 24-12-1122 is not combined with frag. 24-12-1000 and frag. 24-12-1002, the question arises to what kind of scene this fragment could belong. ${ }^{81}$ Given that the hieroglyphs of Kawab's name and a title indicate two different reading directions, I would like to suggest that frag. 24-12-1122 belonged to a second scene of descent which followed the same principles of composition as the genealogical scene of Hetepheres II with mother and daughter facing each other (fig. 5). Kawab is thus to be found on the right hand side, but the "pintail duck" (Gardiner G 39) of the caption of the figure on the left hand side renders it difficult to identify it as a son or daughter of Kawab or as his mother, though the latter seems preferable.

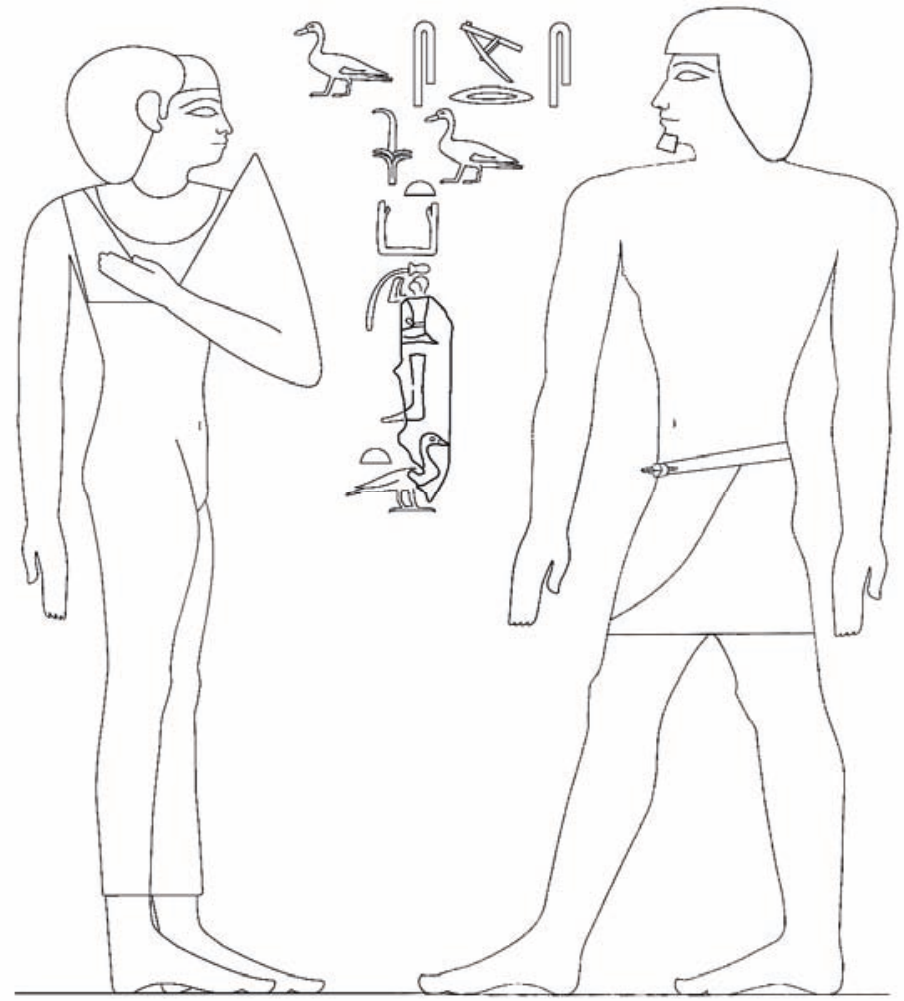

Fig. 5: Conjectural draft of the genealogical scene depicting Kawab and his mother (drawing by R. Gundacker)

At any rate, it is surprising that the string of titles for Kawab's mother starts with a "pintail duck" (Gardiner G 39) indicating the word s3.t "daughter". We thus face only two options: On the one hand, Kawab's mother could have born the title s3.t-njswt "king's daughter". Accord-

${ }^{81}$ Neither W. S. Smith and W. Kelly Simpson nor V. G. Callender have ever addressed this issue. Cf. also n. 127. 
ingly, Kawab should be viewed as the son of a princess and an unknown father, be it a king or not. In spite of this, B. Schmitz ${ }^{82}$ demonstrated that Kawab must have been the son of a king because of his title $s 3-n j s w t ~ s m s ́ w$ "eldest king's son", which to wear was, in the Fourth Dynasty, a privilege of princes of the blood royal. We would thus face the strange situation that a king fathered a boy with a princess and that she perceived her basic title as s3.t-njswt "king's daughter" as so important to have it included in this short caption. Yet, a closer look at the genealogical scenes of Hetepheres II (G 7110/20), ${ }^{83}$ Chaefchufu (G 7140) ${ }^{84}$ and Meresanch III (G 7530sub) ${ }^{85}$ reveals an astounding detail: The mother, a queen in all three instances, never uses a title which straightforwardly makes mention of njswt "the king" as in s3.t-njswt "king's daughter", hm.t-njswt "king's daughter" or, hypothetically, $m w . t$-njswt "king's mother". This is even the more surprising since all those scenes suffer from space constraints and one of those titles would have clarified the mother's rank and status beyond ambiguity. However, such titles only can be found in abundance, e.g., in a scene with sufficient space for long captions of Sechemkare with his mother Hekenuhedjet (LG 89) ${ }^{86}$ and in the very spacious scene with mother (Hetepheres II), daughter (Meresanch III) and grandson (Nebemachet) on the west wall of the main chamber of G 7530sub. ${ }^{87}$ Apparently, queens as mothers preferred to use other components of their title strings when they were depicted in genealogical scenes stating the descent of their children. ${ }^{88}$ Consequently, the title s3.t-njswt "king's daughter" becomes a rather unlikely candidate for the mother in Kawab's scene of descent.

Another title, which can be suggested instead of s3.t-njswt "king's daughter", is s3.t-ntrr "daughter of the god". ${ }^{89}$ It is important to remember that this title is only borne by king's mothers, which provides an exceptional opportunity to identify Kawab's mother. During the reign of Cheops, when Kawab's and Hetepheres II's mastabah (G 7110/20) was built, only the reigning king's mother, Hetepheres $\mathrm{I},{ }^{90}$ held this title in a distinctive variant $s$ 3.t-ntr nj.t h.t $t=f$ "daughter of the god of his body". If this be accepted, Kawab would have been the son of Sneferu and Hetepheres I and, thus, a full brother of Cheops. This definitely contradicts the communis opinio that Kawab was a favourite son of Cheops, allegedly his designated heir and crown prince. ${ }^{91}$ But one has to admit that the reasons for this assumption are comparably

82 Schmitz (1976: 55-57, 91-95).

$83 \mathrm{Cf}$. the reconstruction proposed in section 4 further above.

84 Simpson (1978: 11, pl. XVI (a), fig. 26).

85 Dunham \& Simpson (1974: pl. IV, fig. 4). One should also mention here that s3.t njswt-bjt Hwj=f-wj "the daughter of the King of Upper and Lower Egypt Cheops" cannot be viewed as an unusual variant of Hetepheres II's title s3.t-njswt "king's daughter", but that this is a genuine explanatory statement of genealogical content. For that reason, it was placed in front of Hetepheres II apart from her name and titles.

86 Hassan (1932-1960: IV 117 [fig. 62]); cf. Porter \& Moss (1928-2012: II.2 233-234); Jánosi (2005: 375-379).

87 Dunham \& Simpson (1974: pl. VII, fig. 7).

88 The rest of the genealogical scenes assembled by Schmitz (1976: 46-56) fit this observation.

89 Cf. Schmitz (1976: 134-140); Callender (1991) \& (2011: 329-331); Baud (1999: I 141-149).

90 Reisner (1927a), (1928), (1931: 70-72) \& (1942: 240-242); Smith (1952) \& (1971: 164-166); Lehner (1985); Baud (1999: II 525-527 [no. 162]); Gundacker (2006: 253-264) \& (2006a); Callender (2011: 60-66 [with further bibliographical references]) \& (2012: 64-70).

91 Reisner (1931: 240-241) \& (1942: 28, 373); Smith (1952: 124) \& (1971: 165-166, 170-171); Reisner \& Smith (1955: 3-9); Baer (1960: 140 [no. 513]); Schmitz (1976: 55-57, 66); Porter \& Moss (1928-2012: III.2 187); Simpson (1978: 1-2); Strudwick (1986: 146 [no. 140]); Baud (1999: II 586-587 [no. 230]); Schneider (2002: 100); Dessoudeix (2008: 62-63); Dodson (2010: 58); Stadelmann (2010); Callender (2011: 71-79). It is now 
meagre. Since it can be demonstrated that Meretites was not the mother of Kawab, only two arguments remain in favour of his being a son of Cheops.

The first is that Kawab and his wife Hetepheres II had a tomb (G 7110/20) in the East Field, the necropolis of the royal family of Cheops. This privilege is usually accepted as indicative for his descent from Cheops, but his marriage with Hetepheres II, a daughter of Cheops and Meretites, may equally suffice. ${ }^{92}$ It is thus inadequate to attempt at deducing Kawab's exact family relations from the location of his tomb, which altogether was an idea of G. A. Reisner ${ }^{93}$ but was shown not to work properly by P. Jánosi. ${ }^{94}$

The second piece of evidence is the lower part of a statue found at the temple of Ptah in Memphis, whereto Chaemwaset must have brought it judging from his restoration inscription. ${ }^{95}$ While the front of this statue displays an inscription from the Fourth Dynasty giving Kawab's name and titles, the three sides of the block throne bear a lengthy inscription of Chaemwaset in fourteen columns. Unfortunately, this text is damaged and difficult to understand, but, in line (2), Chaemwaset utters his desire to act for $K 3=j-w^{c} b . j$ "this statue of the king's son Kawab", which he had found in debris. ${ }^{96}$ A passage in line (4), njswt-bjt Hwj=f-wj ${ }^{98}$ "[//////] the beloved of his father, the King of Upper and Lower Egypt Cheops", is crucial for the investigation of Kawab's descent. Taking into consideration the preposition $m$ "in" at the beginning of line (4) and the mention of nj.t $H^{c} j=f-R^{c} w$ "the well (or reservoir) of Chephren" in line (14), this passage, in fact, must be analysed differently. Already F. Gomaà ${ }^{99}$ pointed out that the lacuna must have contained a place name of which only the determinative, the "channel filled with water" (Gardiner N 36), is preserved, which M. Baud took as part of $m r j$ "to love, to desire". And there is yet another difficulty: $j t j=f$ does not only mean "his father", it can also stand more freely for "his forefa-

commonly accepted that there was neither the office nor the title of crown prince during the Old Kingdom, cf. Schmitz (1976: 69, 136 [with n.1]); Stadelmann (1984: 169) \& (2010); Strudwick (1985: 146-147 [no. 140]); Jánosi (1997) \& (2005: 101); Bolshakov (1995); Callender (2011: 83, 93-94, 126).

92 R. Stadelmann's (2010: 299 [n. 19]) objection that, if Kawab as a brother of Cheops was granted a tomb in the East Field, also Hemjunu would have had an equal claim, falls short for three reasons: First, Kawab was a son-in-law of Cheops via his marriage with Hetepheres II, a daughter of Cheops, whereas Hemjunu was certainly not married to a daughter of Cheops if he was married at all (Junker 1929-1955: I 132-162; Schmitz 1976: 68-70, 92-93, 101-105, 127, 329; Baud 1999: II 516-517 [no. 151]; Jánosi 2005: 114-117, 125, 205; Gundacker 2006: 299-302). Second, Hemjunu was not even a brother of Cheops, but, as a son of Nefermaat and Itet, Cheops' nephew (cf. the attestations of Hemjunu in his father's tomb at Maidum; Petrie 1890: pl. V; Junker 1929-1955: I 133, 137-138; Bolshakov 1991; Harpur 2001: 59-61 [fig. 72-74], 69-70 [fig. 78], 80-84 [fig. 81-84], 86-87 [fig. 86], 90 [fig. 90]). Third, the biggest mastabah of all in the East Field, G 7510, was the burial place of Anchhaef, who, according to the communis opinio, is a (half) brother of Cheops and was married to a presumed daughter of Cheops called Hetepheres (cf. Reisner 1942: 81; Reisner \& Smith 1955: 11; Schmitz 1976: 96; Baud 1999: II 424-425 [no. 35]; Jánosi 2005: 110-111; Gundacker 2006: 271-274).

93 Cf. Reisner (1931: 239-242) and the discussion in extenso in Reisner (1942).

94 Jánosi (2005: 58-60, 84-100); cf. also Lehner (1985: 41-42, 51-59, 72-74); Callender (2012).

95 Gomaà (1973: 67-69, 84, 119 [fig. 19], pl. 4); Kitchen (1969-1990: II 872-873); Málek (1992: 62); Fisher (2001: I pl. 139-140, II 125); Snape (2011).

96 Perhaps from Ramesside stone robbery? Cf. n. 15 further above.

97 Baud (1999: II 586 [no. 230]).

98 For Cheops' name and the various spellings of it, cf. Quack (2004); Gundacker (2013: 64-78).

99 Gomaà (1973: 68 [n. b]); cf. Snape (2011: 472-473). 
ther, ancestor". ${ }^{100}$ Since this inscription aims at linking Chaemwaset to the ancestors of the far past, it is not self-evident whether he connects himself to the line of kings by referring to "his forefather" Cheops or whether he speaks of Kawab's father. However, even if this was to be comprehended in such a way that it denoted Cheops as Kawab's father, this inscription still would be separated from Kawab's time by more than a millennium, which casts doubt on its reliability. This inscription is thus ambiguous at best and cannot serve as hard evidence.

After all, it appears much more credible that Kawab was a son of Sneferu ${ }^{101}$ than of Cheops. If we furthermore accept that Hetepheres I was Kawab's mother, as is indicated by frag. 24-12-1122, we may attempt at reconstructing the rest of the inscriptions. With Hetepheres I's special title of s3.t-ntr nj.t h.t=f "daughter of the god of his body" and a statement of descent like in Chaefchufu's and, mutando mutato, Hetepheres II's genealogical scenes, ${ }^{102}$ the following more complete - though highly conjectural - reconstruction may be offered (fig. 6):

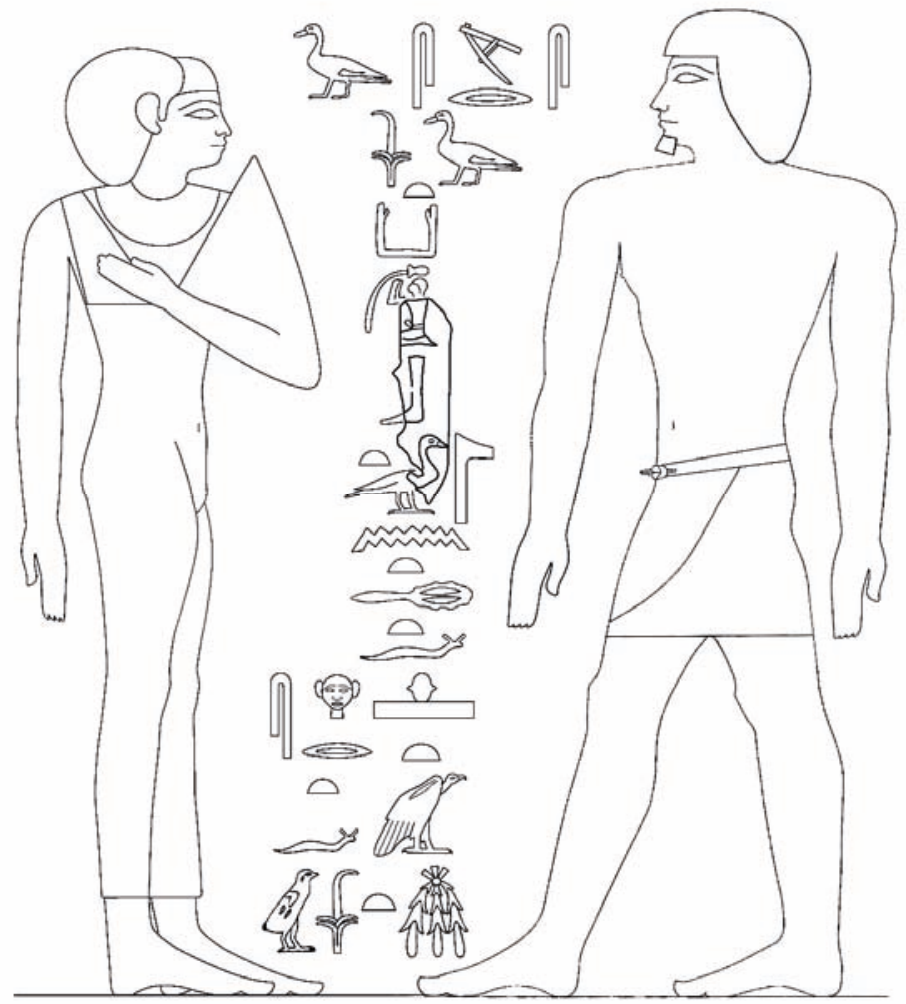

Fig. 6: Conjectural reconstruction of the genealogical scene depicting Kawab and his mother Hetepheres I (drawing by R. Gundacker)

\footnotetext{
${ }^{100}$ Erman \& Grapow (1982: I 141 (16)-(17)).

101 Cf. Jánosi (2005: 101-103); Gundacker (2006: 265-270, 275-284, 298) \& (2008: 28-30, 34-37).

102 Cf. Simpson (1978: 11, pl. XVI (a), fig. 26) and section 4 further above.
} 


\section{Excursus: Kawab and His Homonymous Eldest Son Kawab (the Younger)}

In the offering chamber of Kawab's chapel (G 7120), ${ }^{103}$ on the right hand side, next to the false door, Kawab is depicted together with a son of his and his wife. Accordingly, there can be no doubt that Kawab and Hetepheres II had at least two children, the son mentioned and Meresanch III. An unnumbered fragment ${ }^{104}$ from the west wall of chamber (B) shows Kawab and two small figures behind him, but it is unclear whether these represent two sons of Kawab or personnel. Whether Kawab and Hetepheres had more than two children is impossible to say due to the extreme destruction of the chapel and its reliefs. The only child whose fate is known is Meresanch III, all the others fell into oblivion.

G. A. Reisner and W. S. Smith ${ }^{105}$ estimated that Kawab made arrangements for 10 or maybe 20 statues in the portico and the rooms of his chapel (G 7120), of which only a few larger fragments a numerous splinters remain. The statue mentioned above, which Chaemwaset had transferred to the temple of Ptah in Memphis, certainly was one of them. ${ }^{106}$ The original inscriptions from the Fourth Dynasty on the front side call Kawab jrj- $p^{c} w . t \quad t 3 j t j s 3 b$

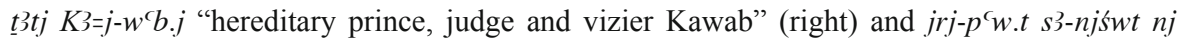
$\underline{h} . t=f K_{3}=j-w^{c} b . j$ "hereditary prince, king's son of his body Kawab" (left). Kawab is thus referred to with the highest titles of office ( $t 3 j t j \xi 3 b \underline{t} 3 t j$ "judge and vizier") ${ }^{107}$ and of court rank.

103 Simpson (1978: 4, pl. VII (a), fig. 5, 15).

104 Simpson (1978: 3, pl. VII (b), fig. 5, 13 [top]).

105 Smith (1949: 30); Simpson (1978: 7).

106 JdE 40431; Gomaà (1973: 67-69, 84, 119 [fig. 19], pl. 4); Kitchen (1969-1993: II 872-873); Simpson (1978: 8 [n. 20]); Málek (1992: 62); Fisher (2001: I pl. 139-140, II 125); Snape (2011).

107 Baer (1960: 140 [no. 513]); Strudwick (1986: 146 [no. 140]); Baud (1999: 586-587 [no. 230]). In fact, this is the only explicit attestation of Kawab as vizier. A fragment from the bottom of a column of text from his chapel (G 7120), frag. 24-12-937, is sometimes thought to mention the title [w]r-dj[w-pr-Dhwtj] "greatest of the five of Toth" (Simpson 1978: 8, fig. 15; Strudwick 1986: 146 [no. 140], 308-309; Baud 1999: II 586 [no. 239]; Jones 2001: no. 1471). This interpretation is, however, very insecure because total transposition of $p r-$ Dhwtj is rare and the division of a title at the transition from one column to another is unheard of in the early Fourth Dynasty. Furthermore, frag. 24-12-937 shows a "mouth" (Gardiner D 21), the supposed complement of the "swallow" (Gardiner G 36), which is highly unusual for this subsidiary title of the vizierate. Another piece from the inscriptions, frag. 24-12-1124 (Simpson 1978: 8, fig. 15), displays a "swallow" (Gardiner G 36), but this alone is insufficient for the conjecture of the title under discussion. This may equally well have formed part of a title like $w r-m 3 w$ "greatest of seers" (a title of the high priest of Heliopolis originally connected to the prospection of quarries, cf. Rahotep's title string, Baud 1999: II 512 [no. 143]; Harpur 2001; cf. in general Helck 1954: 96 \& 1987: 281; Schmitz 1976: 71; Jones 2001: no. 1428) or $w r-m \underline{d} w$-Šs $m^{\prime} w$ " $g r e a t$ one of the ten of Upper Egypt" (perhaps a college of advisors of the king, which developed out of an assembly of local princes in the Early Dynastic Period, cf. Helck 1954: 102 \& 1987: 278, 281; cf. also Jones 2001: no. 1437; R. Stadelmann 2010: 298-299 supposed that this council chose the future king). During the Fourth Dynasty, the title hrp j3.t nb.t ntrj.t "director of every divine mound" was commonly, though not exclusively, borne by viziers (Helck 1954: 52; Strudwick 1986: 315; Jones 2001: no. 2541). Kawab held the very similar title hrp j3.wt ntrj.wt "director of the divine mounds", which may or may not be equivalent with the aforementioned so that this does not represent a firm piece of evidence. Consequently, neither Kawab's sarcophagus nor the fragments of the chapel's reliefs display a definitive trace of a title connected to the vizierate. Only the statue found in Memphis bears witness for Kawab's vizierate, which altogether may indicate that his tomb had been decorated and his sarcophagus inscribed when, at an old age, he was unexpectedly appointed vizier (cf. Baud 1999: II 586-587 [no. 230]; Jánosi 2005: 102-103). Anyway, this remarkable statue proves V. G. Callender's (2011: 100 [n. 61]) opinion that Kawab never had become vizier wrong. 
Further fragments show other parts of Kawab's title string or his name, above all jrj-

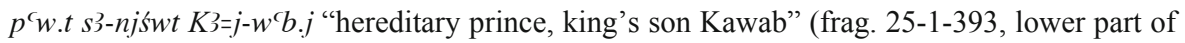
a squatting statue) ${ }^{108}$ and [///] $h 3 t . j-{ }^{-} w K^{3}=j\left[w^{c} b . j\right]$ "[///] duke Ka[wab]" (frag. 24-12-467, fragment of a standing or seated statue). ${ }^{109}$ All these fragments attest the highest titles of Kawab's time, which makes it even the more surprising that there are a few pieces with very modest titles. The most significant example is the lower part of a squatting scribe statue (frag. 34-41a), which was found under a roofing block of the portico (D) and bears three inscriptions: $w r-m \underline{d} w-S^{\zeta} m^{c} w K 3=j-w^{c} b . j$ "great one of the ten of Upper Egypt Kawab" (belt and unrolled papyrus) and [//////] $s 3=f s m s w w r-m \underline{d} w-\zeta^{\zeta} m^{c} w K 3=j-w^{c} b=j$ "[//////] his eldest son, great one of the ten of Upper Egypt Kawab" (front side of the base). ${ }^{110}$ On the base, the traces before the name allow for no restoration, but they definitely do not fit a cartouche so that a special kind of reference to a king as the father ${ }^{111}$ can be excluded. ${ }^{112}$ Even though the quality of the statue is good, the titles are so unexpectedly low-ranking that Kawab does not seem a fitting candidate. This holds particularly true since the title $s 3-n j s w t$ "king's son" is missing and there is no unambiguous attestation of the title $w r-m \underline{d} w-S m^{c} w$ "great one of the ten of Upper Egypt" for Kawab. ${ }^{113}$ It is thus tempting and plausible to posit that this statue represented a son of Kawab and Hetepheres II who was named after his father. It may well be that Kawab had this statue made and erected in the portico (D) of his chapel, but that, some time later, a homonymous son of his had these inscriptions added. Whether or not Kawab (the Younger) is identical with the boy depicted together with his parents in the offering chamber (A) of Kawab's chapel (G 7120 ) is unknown, but the fact that the inscriptions of this statue cannot refer to the king's son Kawab is supported by M. Baud and V. G. Callender. ${ }^{114}$ Another piece of a statue (frag. 2412-339) ${ }^{115}$ was found in the avenue south of mastabah G 7220 and displays the title $s m h r-w^{c} j t j$ nj mrw.t "sole companion out of affection" which is a title honoris causa ${ }^{116}$ and appears thus unfitting for a prince of the blood royal who held much more prestigious titles. Finally, frag.

108 Simpson (1978: 7, fig. 18).

109 Simpson (1978: 8, fig. 18).

110 Simpson (1978: 7, fig. 17-18); cf. also photographs B8338_NS, B8339_NS and SC127287 (accessed via The Giza Archives, http://www.gizapyramids.org/). The offering formula of the third quotation is omitted here.

111 Cf. Edel (1953: 336) \& (1955-1964: I §§ 306-307); Schmitz (1976: 46-48).

112 M. Baud (1999: II 586-587 [no. 230]) pointed out that even if no text is missing, $s 3=f$ s $m$ św "his eldest son" may rely on an external point of reference, most likely a relief or a nearby statue. If so, Kawab must be the father because statues or depictions of the king are unattested in the tomb chapels of commoners during the

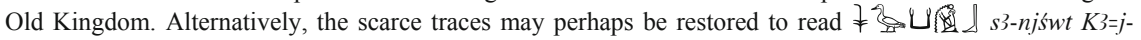
$w^{c} b=j$ "the king's son Kawab", which would settle the debate, but this remains entirely uncertain.

113 It is important to stress that $s\}=f s m s w$ "his eldest son" is not a form of or an adequate replacement for the title of s3-njśwt "king's son" (Gundacker 2006: 276 \& 2008: 33).

114 Baud (1999: II 586-587 [no. 230]); Callender (2011: 101). R. Stadelmann's (2010: 299 [n. 19]) allegation that I "invent[ed] a mysterious first consort and a son with identical name" for no reason is therefore to be rejected. Whether or not Hetepheres II was the second wife of Kawab remains a matter of debate and solely depends on the deduced age of Kawab, which itself depends on when he may have been born, rather early as a son of Sneferu or rather late as a son of Cheops. From the available data, a marriage of Kawab with another woman before he wedded Hetepheres II is at least not precluded (cf. Jánosi 2005: 102-103).

115 Simpson (1978: 7, fig. 18).

116 Cf. Fischer (1978: 49); Hannig (2003: 1141-1142); for a slightly different understanding of this epithet, cf. Baud (1999: I 265); Jones (2001: no. 1753, 3277); cf. also Gundacker (2006: 276) \& (2008: 33 ). 
24-12-201 must be mentioned, which was found in the G 7100 street near Hetepheres II's

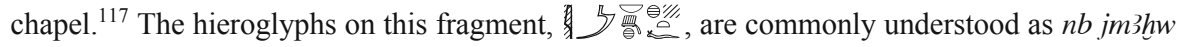
$h f t[/ / /]$ "lord of reverence opposite of [///]", but instead of $h f t$ "opposite of" one would expect $h r$ "at, with". However, the arrangement of the hieroglyphs, which are mediocre in style, is fairly strange so that the following alternative may at least be worth consideration: $n b$-jm3hw $h[r] j t j=f$ "lord of reverence bef[ore] his father". 118 In order to achieve this, a "mouth"

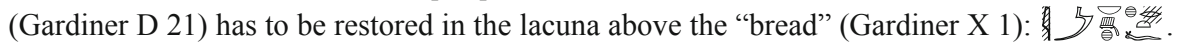
Since two subsidiary mastabahs (G 7111 and G 7112) ${ }^{119}$ are located near the findspot of this fragment, the statue, to which this fragment once belonged, may have been owned by a man who was buried in a shaft associated with one of the subsidiary mastabahs. ${ }^{120}$

Regrettably, it remains unknown whether the owners of those subsidiary tombs were offspring of Kawab and Hetepheres II, or otherwise related to them, or not. It is tempting to interpret $n b$-jm3hw $h[r] j t j=f$ "lord of reverence before his father" as a phrase incised for a son or grandson of Kawab and Hetepheres II with $j t j=f$ "his (grand)father" referring to Kawab, but the available data is insufficient to substantiate this claim. With reference to the miniature vessels and other burial equipment, which G. A. Reisner found in the burial apartments of those subsidiary mastabahs, it is at least safe to say that the burials were interred in the later Fourth and early Fifth Dynasties, ${ }^{121}$ which at least does not exclude such a conclusion.

We may thus summarise that Kawab and Hetepheres had, in addition to Merisanch III, their daughter, at least one son, maybe two. According to a statue fragment (frag. 34-4-1a) bearing distinctly different and rather low-ranking titles when compared to Kawab's, one son was also called Kawab, just like his father. Unfortunately, there is no information about this son, Kawab (the Younger), and the fate of this branch of the family.

\section{Conclusion}

The extremely fragmentary state of the reliefs from the chapels of Kawab and Hetepheres II (G 7120 and G 7110) renders it tremendously difficult to draw any far reaching conclusions. Every scattered piece of information requires fantasy and creativity in order to draft overarching theories, but, at the same time, one has to stay with the regrettably few hard facts. How difficult this process can be is best demonstrated by G. A. Reisner's, W. S. Smith's and W. K. Simpson's ingenious conclusions, assumptions and reconstructions, which nevertheless have become too fanciful and too extravagant in the periphery. Nevertheless, the very core of their observations remains invaluable and irreplaceable. Every attempt to assess the history of the early Fourth Dynasty must therefore start from their work, with all due respect, but also with the courage to change what appears implausible in the light of more recent research.

\footnotetext{
${ }_{117}$ Simpson (1978: 8, fig. 17).

${ }^{118}$ In the Fourth and Fifth Dynasties, this phrase is attested several times; for references, cf. Hannig (2003: 137).

${ }^{119}$ Simpson (1978: 28-31).

${ }^{120}$ Three more fragments show traces of the name Kawab (25-1-1313, 24-12-978, V (?)), but this is insufficient for any further conclusion (Simpson 1978: 8, fig. 17).

${ }^{121}$ Cf. a sealing with the name of king Nirewoser in the latest of the six shafts (G 7112A; Simpson 1978: 28; Reisner \& Smith 1955: 53, fig. 52).
} 
Under this premise, the present article has re-evaluated the material which is commonly used to define the lineage of Kawab and Hetepheres II. A close examination of the fragments traditionally involved in Kawab's supposed genealogical scene (frag. 24-12-1000, frag. 24-12-1002, frag. 24-12-1122) revealed significant difficulties, above all, that the findspots of all three fragments are unknown and that their attribution to the chapel of Kawab (G 7120) or Hetepheres II (G 7110) is conjectural. Moreover, the philological analysis of the text remains produced valuable results. It is particularly important to stress that the preserved inscriptional evidence found on frag. 24-12-1000, i.e., a dependent personal pronoun $s j$ "she", proves that the respective scene was about the descent of a woman, which must be Hetepheres II. For that reason, it is possible to reconstruct a genealogical scene which states that Hetepheres II was borne to Cheops by Meretites (frag. 24-12-1000 and frag. 24-12-1002). This first scene of descent is in full accord with further information known from the so-called stela of Meretites and from depictions of Hetepheres II in the tomb of her daughter Meresanch III (G 7530sub). At the same time, frag. 24-12-1122 allowed us to propose a second scene of descent which deals with the lineage of Kawab. In case the discussion above finds agreement, Kawab can be identified as a son of Hetepheres I and Sneferu, and thus a full brother of Cheops. Naturally, one would assume that Kawab was a younger brother of Cheops, but since Kawab was unexpectedly appointed vizier when his tomb was completed, so that this new title only was added on at least one statue, it appears more plausible that he was an elder brother of Cheops. ${ }^{122}$ Accordingly, Kawab would have been a grown up man at the time of the accession of Cheops, but Hetepheres II was not yet born. The stela of Meretites clearly states that she, perhaps as a queen-consort, was first connected to the court of Sneferu and then to the court of Cheops. Therefore, Hetepheres II cannot have been born before the early years of Cheops', but a time much later is also excluded because she was a grown up woman before the accession of Redjedef who most likely became her second husband. As a result, Kawab could have been married with another woman before he wedded Hetepheres II, though there is no firm evidence. From the scattered reliefs and statue fragments, we know that Kawab and Hetepheres II had at least two children, Kawab (the Younger) and Meresanch III, but maybe also a second son. ${ }^{123}$

The extreme destruction of Kawab's chapel (G 7120) renders it very difficult to ascribe the two genealogical scenes to a specific wall. Referring to the work of W. S. Smith and W. K. Simpson, ${ }^{124}$ it is the best and most elegant solution to assign the scene which relates the

${ }^{122}$ This leaves us with concerns with regards to the mode of royal succession, but in the end this is due to a very much Eurocentric expectation of clearly defined succession rules after the model of (Semi-)Salic law. In the end we have to confess that the principles and laws of royal succession are unknown for the Old Kingdom. Cf. Schmitz (1976: 69, 136 [with n.1]); Stadelmann (1984: 169) \& (2008); Strudwick (1985: 146-147 [no. 140]); Jánosi (1997) \& (2005: 101); Bolshakov (1995); Callender (2011: 83, 93-94, 126).

${ }^{123}$ This is also interesting in the light of the recent discussion on regnal lengths, because of the time needed for Hetepheres to grow up and bear (at least) two children for Kawab. It seems difficult to see this fit into a reign of much less than 25 years, which is in accord with the regnal years attested in the western desert (Kuhlmann 2005) and in the papyri from Wadi el-Jarf (Tallet 2017). Even though this is hardly more than general suppositions, it might speak in favour of the traditional model of cattle counts being carried out on a regular biennial basis during the Fourth Dynasty (cf. Gundacker 2006: 315-342 \& 2015a vs. Nolan 2003, 2008 \& 2015; cf. also the contribution of Verner 2001, 2006 \& 2008). Whatever the case may be, this crucial problem of Old Kingdom chronology cannot be discussed here on a broader basis for reasons of time and space.

${ }^{124}$ Simpson (1978: 3, fig. 5). 
descent of Kawab to the façade of the offering chamber (A), which is the west wall of room (B). By contrast, it is much more difficult to find a suitable setting for the genealogical scene of Hetepheres II. Given the problems with the archaeological circumstances, it is of course possible that this scene of descent formed part of the decoration in the chapel of Hetepheres II (G 7110), of which hardly any fragments survived. ${ }^{125}$ However, if the fragments were found in or near Kawab's chapel (G 7120) and if one is willing to accept this as indicative for their origin, this genealogical scene may have belonged to room (B). According to this proposition, the southern portion of the west wall of this room would have displayed, from south to north, the genealogical scene of Kawab and a large relief depicting Kawab with two sons or servants. Right in between these two scenes was situated the door to the offering chamber (A), which was built into the core of the mastabah. The northern portion of this same wall contained provisions for some of the statues of Kawab. The north wall was dominated by the entrance door from room (C), and the south wall cannot have been the place of origin of the genealogical scene of Hetepheres II because of a window. It is thus the east wall which may have held the scene relating Hetepheres II's descent. Since frag. 24-12-1002 apparently shows the remains of a limiting line on the left hand side, Hetepheres II's scene of descent may have opened the east wall of chamber (B) next to the north wall with the entrance door from room (C). In case this impression is correct, the entire chamber was dominated by a relief programme relating the family history with Hetepheres II's descent near the northeast corner, with Kawab's descent near the southwest corner, and with a scene depicting Kawab and, perhaps, two sons on the west wall which furthermore contained several statue niches. ${ }^{126}$ Yet another representation of Kawab, this time watching country life and various activities of daily life, was certainly an additional dominating element in the supposed programme of large scale representations of family members. ${ }^{127}$ In between the genealogical scene of Hetepheres II and Kawab, scenes of bird and game hunt, of slaughtering oxen, of fishing, of papyrus production, a scene involving a herdsmen, a boat scene and others more had their place. ${ }^{128}$

It is obvious that every attempt to reconstruct the relief programme of the chapels of mastabah G 7110/20 is extremely difficult. This not only holds true for the decoration programme as a whole, but also for individual scenes, in particular the genealogical scenes of Kawab and Hetepheres II. Whether or not the reconstruction of those scenes and of their background as proposed here fit the bigger picture of history, must be left to future research.

${ }^{125}$ Simpson (1978: 4-5, pl. IX (c), fig. 16).

${ }^{126}$ Cf. Simpson (1978: 2-4, fig. 5).

${ }^{127}$ If, beforehand, one is not willing to accept that frag. 24-12-1122 formed part of a genealogical scene, it appeared possible that, alternatively, this fragment formed part of a scene with Hetepheres II (right hand side) and Kawab (left hand side) facing each other. Then, the remains of the woman's title on the left hand side indeed could be restored to $s 3[. t-n j \xi w t]$ "king's daughter", which would be followed by her name. Beyond that, however, I have no persuading idea with what to fill the rest of the space between the two figures (perhaps a child?). As a final point, content and message of this scene would remain a mystery, and I know of no such scene with husband and wife facing each other from the Old Kingdom (cf. Harpur 1987). For that reason, this should be considered an extremely unlikely solution which is very much inferior to genealogical scene.

${ }^{128}$ Simpson (1978: 3). There was another depiction of Hetepheres II on the western portion of the north wall of chamber (B), perhaps facing Kawab opposite the door (Simpson 1978: 2, pl. V (b), fig. 10 (C); cf. section 4 ad frag. 24-12-861). Obviously, Kawab and Hetepheres were both prominently represented in chapel G 7120. 


\section{Bibliography}

Baer, Klaus. 1960. Rank and Title in the Old Kingdom. The Structure of the Egyptian Administration in the Fifth and Sixth Dynasties, Chicago.

Baud, Michel. 1999. Famille royale et pouvoir dans l'Ancien Empire égyptien, 2 voll., Bibliothèque d'Étude 126, Cairo.

- 2005. The Birth of Biography in Ancient Egypt. Text, Format and Context in the IV ${ }^{\text {th }}$ Dynasty, in: Johannes Seidelmayer (ed.), Texte und Denkmäler des ägyptischen Alten Reiches, Thesaurus Linguae Aegyptiacae 3, Berlin, 91-124.

Bolshakov, Andrey O. 1991. Some observations on the early chronology of Meidum, in: Göttinger Miszellen 123, 11-20.

— 1995. Princes who became kings. Where are their tombs? in: Göttinger Miszellen 146, 11-22.

Borchardt, Ludwig. 1937-1964. Denkmäler des Alten Reiches (außer den Statuen) im Museum von Kairo (Nr. 1295-1808), 2 voll., Kairo.

Callender, Vivienne Gae. 1991. A contribution to the discussion on the title of s3t ntrr, in: Studien zur Altägyptischen Kultur 18, 89-111.

— 1992. The Wives of the Egyptian Kings. Dynasties I-XVII, 3 voll., unpublished PhD dissertation, Sydney.

— 2002. A. Contribution to the Burial of Women in the Old Kingdom, in: Filip Coppens (ed.), Abusir and Saqqara in the Year 2001. Proceedings of the Symposium (Prague, September $25^{\text {th }}-27^{\text {th }}$, 2001), Archiv Orientální 70, Prague, 301-308.

-2011. In Hathor's Image I: The Wives and Mothers of Egyptian Kings from Dynasties I-VI, Prague.

— 2012. Some notes concerning Reisner's royal family history of the Fourth Dynasty, in: Linda Evans (ed.) Ancient Memphis. 'Enduring is the Perfection'. Proceedings of the International Conference Held at Macquarie University, Sydney on August 14-15, 2008, Orientalia Lovaniensia Analecta 214, Leuven, 63-84.

Dessoudeix, Michel. 2008. Chronique de l'Égypte ancienne. Les pharaons, leur règne, leurs contemporains, Arles.

Dodson, Aidan. 2010. The Complete Royal Families of Ancient Egypt, London.

Dorman, Peter. 2002. The Biographical Inscription of Ptahshepses from Saqqara: A Newly Identified Fragment, in: Journal of Egyptian Archaeology 88, 85-109.

Dunham, Dows and William Kelly Simpson 1974. The mastaba of Queen Mersyankh III. G 7530-7540: based upon the excavations and recordings of the late George Andrew Reisner and William Stevenson Smith. Museum of Fine Arts - Harvard University Expedition. Giza Mastabas 1. Boston

Edel, Elmar. 1953. Inschriften des Alten Reichs III-IV, in: Mitteilungen des Instituts für Orientforschung 1, 327336.

— 1955-1964. Altägyptische Grammatik, Analecta Orientalia 34/39, 2 voll., Rome.

— 1970. Das Akazienhaus und seine Rolle in den Begräbnisriten des alten Ägyptens, Münchner Ägyptologische Studien 24, Berlin.

Erman, Adolf \& Hermann Grapow. 1982. Wörterbuch der ägyptischen Sprache, 6 voll., and Belegstellen, 6 voll., reprint, Leipzig \& Berlin.

Federn, Walter. 1934. Zur Familiengeschichte der IV. Dynastie Ägyptens, unpublished PhD dissertation, Vienna.

— 1935. Zur Familiengeschichte der IV. Dynastie Ägyptens, in: Wiener Zeitschrift für die Kunde des Morgenlandes 42, 165-192.

Fischer, Henry G. 1960. The butcher ph-r-nfr, in: Orientalia 29, 168-190.

— 1964. Graphic Transposition of the Indirect Genitive, in: Journal of the American Research Center in Egypt 3, 123-124.

— 1978. Five inscriptions of the Old Kingdom, in: Zeitschrift für Ägyptische Sprache und Altertumskunde 105, 42-59.

— 1996. Egyptian Studies III. Varia Nova, New York.

Fisher, Marjorie M. 2001. The sons of Ramesses II, 2 voll., Ägypten und Altes Testament 53, Wiesbaden.

Flentye, Laurel Ann. 2006. The Decorated Elite Mastaba and Rock-cut Tomb in the Eastern and GIS Cemeteries at Giza and their Relationship to the Development of Art during the Fourth Dynasty, $\mathrm{PhD}$ dissertation, New York. 
Gardiner, Sir A. H. 1938. The House of Life, in: Journal of Egyptian Archaeology 24, 157-179.

Gomaà, Farouk. 1973. Chaemwese, Sohn Ramses' II. und Hoherpriester von Memphis, Ägyptologische Abhandlungen 27. Wiesbaden

Gundacker, Roman. 2006. Untersuchungen zur Chronologie der Herrschaft Snofrus, Beiträge zur Ägyptologie 22 = Veröffentlichungen der Institute für Afrikanistik und Ägyptologie der Universität Wien 104, Vienna.

—2006a. Hetepheres I. und das Rätsel ihrer Bestattung, in: Sokar 12, 30-39

-2008. Ein Beitrag zur Genealogie der 4. Dynastie, in: Sokar 16, 26-55.

— 2010. Ein Beitrag zur Genealogie der 4. Dynastie Teil 2: Die späte und ausgehende 4. Dynastie, in: Sokar 20, 32-46.

— 2010a. Eine besondere Form des Substantivalsatzes. Mit besonderer Rücksicht auf ihre dialektale und diachrone Bedeutung, in: Lingua Aegyptia 18, 41-117.

— 2013. Die Eigennamen der Könige der IV. Dynastie. Ihre Struktur und Bedeutung gemäß ägyptischen und griechischen Graphien, Lingua Aegyptia 21, 35-130.

— 2015. Die (Auto)Biographie des Schepsesptah von Saqqarah. Ein neuer Versuch zur Rekonstruktion der Inschrift und ein Beitrag zur stilistischen Grundlegung des wiederhergestellten Textes, in: Lingua Aegyptia 23, 61-105.

- 2015a. The chronology of the third and fourth dynasties according to Manetho's Aegyptiaca, in: Peter Der Manuelian \& Thomas Schneider (edd.), Towards a new history for the Egyptian Old Kingdom. Perspectives on the pyramid age. Harvard Egyptological Studies 1, . Leiden \& Boston, 76-199.

— 2016. Weitere Zeugen für den Gebrauch des abhängigen Personalpronomens im Substantivalsatz. Zugleich ein Nachtrag zur Besprechung von K. Scheele-Schweitzer, „Die Personennamen des Alten Reiches. Altägyptische Onomastik unter lexikographischen und sozio-kulturellen Aspekten“, in: Bibliotheca Orientalis LXXII, 2015, 637-647, in: Göttinger Miszellen 250, 101-110.

— in print. Retention or Rejection: The Fate of 'Ältere Komposita' at the Transition from the 'Dreisilbengesetz' to the 'Zweisilbengesetz', in: Andrea Kahlbacher \& Elisa Priglinger (edd.), Proceedings of the $5^{\text {th }}$ International Congress of Young Egyptologists, Vienna, $15^{\text {th }}$ to $19^{\text {th }}$ September 2015, Vienna, ca. 54 pp.

Hannig, Rainer. 2003. Ägyptisches Wörterbuch I, Altes Reich und Erste Zwischenzeit, Hannig-Lexica 4, Kulturgeschichte der Antiken Welt 98, Mainz am Rhein.

Harpur, Yvonne. 1987. Decoration in Egyptian Tombs of the Old Kingdom. Studies in Orientation and Scene Content, London.

- 2001. The tombs of Nefermaat and Rahotep at Maidum. Discovery, Destruction and Reconstruction, Egyptian Tombs of the Old Kingdom 1. Prestbury, Cheltenham

Hassan, Selim. 1932-1960. Excavations at Gîza, 10 voll., Kairo.

Helck, Wolfgang. 1954. Untersuchungen zu den Beamtentiteln des ägyptischen Alten Reiches, Ägyptologische Forschungen 18, Glückstein.

— 1986. Tjaisepef, in: Wolfgang Helck \& Wolfhart Westendorf (edd.), Lexikon der Ägyptologie, vol. VI, Wiesbaden, 607.

— 1987. Untersuchungen zur Thinitenzeit, Ägyptologische Abhandlungen 45, Wiesbaden.

James, Thomas G. H. 1961. British Museum. Hieroglyphic Texts from Egyptian Stelae etc., vol. I, second edition, London.

Jánosi, Peter. 1996. Die Pyramidenanlagen der Königinnen. Untersuchungen zu einem Grabtyp des Alten und Mittleren Reiches, Österreichische Akademie der Wissenschaften Denkschriften XIII, Vienna.

— 1997. Gab es Kronprinzen in der 4. Dynastie? „Kronprinz“ Iunre, in: Göttinger Miszellen 158, 15-32.

— 2002. Aspects of Mastaba Development: The Position of Shafts and the Identification of Tomb Owners, in: Filip Coppens (ed.), Abusir and Saqqara in the Year 2001. Proceedings of the Symposium (Prague, September $\left.25^{\text {th }}-27^{\text {th }}, 2001\right)$, Archiv Orientální 70, Prague, 337-350.

— 2005. Giza in der 4. Dynastie. Die Bangeschichte und Belegung der Nekropole des Alten Reiches. I: Die Mastabas der Kernfriedhöfe und die Felsgräber, vol. I, Österreichische Akademie der Wissenschaften Denkschriften XXX, Vienna.

Jones, Dillwyn. 2001. An Index of Ancient Egyptian Titles, Epithets and Phrases of the Old Kingdom, British Archaeological Reports International Series 866, London.

Junker, Hermann. 1929-1955. Gîza. Bericht über die von der Akademie der Wissenschaften in Wien auf gemeinsame Kosten mit Dr. Wilhelm Pelizaeus unternommenen Grabungen auf dem Friedhof des Alten Reiches bei den Pyramiden von Gîza, 12 voll., Vienna. 
el-Khadragy, Mahmoud. 2005. The Offering Niche of Sabu/Ibebi in the Cairo Museum in: Studien zur Altägyptischen Kultur 33, 169-199.

Kitchen, Kenneth A. 1969-1990. Ramesside Inscriptions. Historical and Biographical, 8 voll., Oxford.

— 1991. Towards a Reconstruction of Ramesside Memphis, in: Edward Bleiberg \& Rita Freed (edd.), 1991. Fragments of a Shattered Visage. The Proceedings of the International Symposium of Ramesses the Great, Monographs of the Institute of Egyptian Art and Archaeology 1, Memphis, 87-104.

Kloth, Nicole. 2002. Die (auto-) biographischen Inschriften des ägyptischen Alten Reiches: Untersuchungen zu Phraseologie und Entwicklung, Studien zur Altägyptischen Kultur Beihefte 8, Hamburg.

Kuchman Sabbahy, Lisa. 1982. The development of the titulary and iconography of the ancient Egyptian queen from Dynasty One to early Dynasty Eighteen, unpublished $\mathrm{PhD}$ dissertation, Toronto.

Kuhlmann, Klaus-Peter. 2005. Der „Wasserberg des Djedefre“ (Chufu 01/1). Ein Lagerplatz mit Expeditionsinschriften der 4. Dynastie im Raum der Oase Dachla, in: Mitteilungen des Deutschen Archäologischen Instituts, Abteilung Kairo 61, 243-289.

Lapp, Günther. 1986. Die Opferformel des Alten Reiches: unter Berücksichtigung einiger späterer Formen, Sonderschrift des Deutschen Archäologischen Instituts, Abteilung Kairo 21, Berlin.

Lehner, Mark. 1985. The Pyramid Tomb of Hetep-heres and the Satellite Pyramid of Khufu, Sonderschriften des Deutschen Archäologischen Instituts, Abteilung Kairo 19, Mainz am Rhein.

Leitz, Christian. 2002-2003. Lexikon der ägyptischen Götter und Götterbezeichnungen, 7 voll., Orientalia Lovaniensia Analecta 110-116, Louvain, Paris \& Dudley.

Lepsius, Carl Richard. 1849-1913. Denkmäler aus Ägypten und Äthiopien, tomes I-XII plus a supplementary volumne, Berlin.

Málek, Járomir. 1992. A meeting of the old and new: Saqqâra during the New Kingdom, in: Alan B. Lloyd (ed.) Studies in Pharaonic Religion and Society in Honour of J. Gwyn Griffiths, Egypt Exploration Society, Occasional Publications 8, London, 57-76.

Mariette, Auguste. 1885. Les mastabas de l'Ancien Empire. Fragment du dernier ouvrage de A. Mariette, publié d'après le manuscrit de l'auteur par G. Maspero, Paris.

Martin-Pardey, Eva. 1980. Kawab, in: Wolfgang Helck \& Wolfhart Westendorf (edd.), Lexikon der Ägyptologie, vol. III, Wiesbaden, 378-379.

de Morgan, Jacques. 1895-1903. Fouilles à Dahchour, 2 voll., Vienna.

Nolan, John S. 2003. The original lunar calendar and cattle counts in Old Kingdom Egypt, in: Susanne Bickel \& Antonio Loprieno (edd.), Basel Egyptology prize 1: Junior research in Egyptian history, archaeology, and philology. Aegyptiaca Helvetica 17, Basel, 75-97.

— 2008. Lunar intercalations and "cattle counts" during the Old Kingdom. The hebsed in context, in: Hana Vymazalová \& Miroslav Bárta (edd.), Chronology and archaeology in ancient Egypt (the third millennium B.C.), Prague, 44-60.

— 2015. Cattle, kings and priests. Phyle rotations and Old Kingdom civil dates, in: Peter Der Manuelian \& Thomas Schneider (edd.), owards a new history for the Egyptian Old Kingdom: perspectives on the pyramid age, Harvard Egyptological Studies 1, Leiden, 337-365

Petrie, Sir William M. F. 1890. Medum, London.

Porter, Berta \& Rosalind L. B. Moss. 1928-2012. Topographical Bibliography of Ancient Egyptian Hieroglyphic Texts, Reliefs and Paintings, 8 voll., in part $2^{\text {nd }}$ edition by Jaromír Málek, Oxford.

Posener-Kriéger, Paule. 1991. Graffiti on the Revetment Blocks of the Pyramid, in: Ali el-Khouli (ed.). Meidum, Australian Centre of Egyptology Reports 3, Sydney, 17-21, pl. 7-12.

Quack, Joachim F. 2004. Von

Reisner, George A. 1924. Excavation Diary, vol. XI, unpublished, Gizah (accessed via The Giza Archives at http://www.gizapyramids.org/).

— 1927. Hetep-Heres, Mother of Cheops, in: Bulletin of the Museum of Fine Arts 25, 2-36.

- 1927a. The Tomb of Meresankh, a Great-Granddaughter of Queen Hetep-Heres I and Sneferuw, in: Bulletin of the Museum of Fine Arts 25, 64-79.

— 1928. The empty sarcophagus of the mother of Cheops, in: Bulletin of the Museum of Fine Arts 26, 76-88

- 1929. Nefertkauw, the eldest daughter of Sneferuw, in: Zeitschrift für Ägyptische Sprache und Altertumskunde 64, 97-99, pl. I-III.

- 1931. Mycerinus. The Temples of the Third Pyramid at Giza, Cambridge.

- 1934. The servants of the ka, in: Bulletin of the Museum of Fine Arts 32, 2-12.

- 1942. A History of the Giza Necropolis, vol. I, Boston.

Reisner, George A.; Smith, William S. 1955. A History of the Giza Necropolis, vol. II, The Tomb of Hetep-Heres the Mother of Cheops. A Study of Egyptian Civilization in the Old Kingdom, Cambridge/Massachusetts. 
Roth, Silke. 2001. Die Königsmütter des Alten Ägypten von der Frühzeit bis zum Ende der 12. Dynastie, Ägypten und Altes Testament 46, Wiesbaden.

de Rougé, Emmanuel. 1866. Recherches sur les monuments qu'on peut attribuer aux six premières dynasties de Manéthon, Mémoires de l'Académie des Inscriptions et Belles-Lettres XXV. Paris.

— 1877-1879. Inscriptions hiéroglyphiques copiées en Égypte, 4 voll., Paris.

Schmitz, Bettina. 1976. Untersuchungen zum Titel S3-NJŚWT „,Königssohn“, Bonn.

Schneider, Thomas. 2002. Lexikon der Pharaonen, Düsseldorf.

Seipel, Wilfried. 1980. Untersuchungen zu den ägyptischen Königinnen der Frühzeit und des Alten Reichs. Quellen und historische Einordnung, Hamburg.

Sethe, Kurt. 1933. Urkunden des ägyptischen Altertums, vol. I, Urkunden des Alten Reiches, Leipzig.

Simpson, William K. 1974.

- 1978. The Mastabas of Kawab, Khafkhufu I and II. G.7110-20, G.7130-40 and G.7150, Giza Mastabas 3, Boston.

Smith, William Stevenson 1942. The origin of some unidentified Old Kingdom reliefs, in: The American Journal of Archaeology 46, 509-531.

- 1949. A History of Egyptian Sculpture and Painting in the Old Kingdom, $2^{\text {nd }}$ edition, London.

- 1952. Inscriptional Evidence for the History of the Fourth Dynasty, in: Journal of Near Eastern Studies 11, 113-128.

- 1971 (pre-published in 1963). Chapter XIV. The Old Kingdom in Egypt and the Beginning of the First Intermediate Period, in: Iorwerth E. S. Edwards, Cyril J. Gadd \& Nicholas G. L. Hammond (edd.), The Cambridge Ancient History, vol. I.2, Early history of the Middle East, $3^{\text {rd }}$ revised edition, Cambridge, 145-207.

Snape, Steven. 2011. Khaemwese and the Present Past. History and the Individual in Ramesside Egypt, in: Mark Collier \& Steven Snape (edd.), Ramesside Studies in Honour of K. A. Kitchen, Bolton, 465-473.

— 2017. Some Ramesside Appropriations of Ancient Memphis, in: Mladen Tomorad \& Joanna PopielskaGrzybowska (edd.), Egypt 2015. Perspectives of Research. Proceedings of the Seventh European Conference of Egyptologists, $2^{\text {nd }}-7^{\text {th }}$ June 2015, Zagreb, Croatia, Archaeopress Egyptology 18, Oxford, 187-195.

Stadelmann, Rainer. 1984. Khaefkhufu = Chephren: Beiträge zur Geschichte der 4. Dynastie, in: Studien zur Altägyptischen Kultur 11, 165-172.

— 2010. The Prince Kawab, Oldest Son of Khufu, in: Sue H. D'Auria (ed.), Offerings to the Discerning Eye. An Egyptological Medley in Honor of Jack A. Josephson, Culture and History of the Ancient Near East 38, Leiden \& Boston, 295-299.

Stadelmann, Rainer \& Nicole Alexanian. 1998. Die Friedhöfe des Alten und Mittleren Reiches in Dahschur. Bericht über die im Frühjahr 1997 durch das Deutsche Archäologische Institut Kairo durchgeführte Felderkundung in Dahschur, in: Mitteilungen des Deutschen Archäologischen Instituts, Abteilung Kairo 54, 293-317.

Strudwick, Nigel C. 1985. Three Monuments of Old Kingdom Treasury Officials, in: Journal of Egyptian Archaeology 71, 43-51, pl. III-IV.

— 1986. The Administration of Egypt in the Old Kingdom. The Highest Titles and Their Holders, London.

Tallet, Pierre. 2017. Les papyrus de la Mer Rouge I. Le " Journal de Merer » (Papyrus Jarf A et B). Mémoires Publiés par les Membres de l'Institut Français d'Archéologie Orientale du Caire 136, Cairo.

Troy, Lana. 1986. Patterns of Queenship in Ancient Egyptian Myth and History, Acta Universitatis Upsaliensis, Boreas 14, Uppsala.

Verner, Miroslav. 2001. Archaeological Remarks on the $4^{\text {th }}$ and $5^{\text {th }}$ Dynasty Chronology, in: Archiv Orientálni $69,363-418$.

— 2006. Contemporaneous evidence for the relative chronology of Dyns. 4 and 5, in: Erik Hornung, Rolf Krauss \& David A. Warburton (edd.), Ancient Egyptian chronology, Handbuch der Orientalistik, Erste Abteilung, Der Nahe und Mittlere Osten vol. 83, Leiden, 124-143.

— 2008. The system of dating in the Old Kingdom, in: Hana Vymazalová \& Miroslav Bárta (edd.), Chronology and archaeology in ancient Egypt (the third millennium B.C.). Prague, 23-43.

Ziegler, Christiane. 1979. La Fausse-Porte du Prince Kanefer « Fils de Sneferu », in: Revue d'Égyptologie 31, 121-134, pl. 7-9. 